\title{
Cretaceous cultch: substrate availability for the oyster Exogyra in the Maastrichtian of the eastern Mississippi Embayment
}

\author{
${ }^{1}$ Mississippi State University, Department of Geosciences, Box 5448, \\ Mississippi State, Mississippi 39762, USA. \\ ${ }^{2}$ Mississippi Museum of Natural Science, \\ 2148 Riverside Drive, Jackson, Mississippi 39202, USA. \\ *george.phillips@mmns.ms.gov,**RClary@geosci.msstate.edu
}

Marvin Kunath ${ }^{1}$, George Phillips ${ }^{2, *}$, and Renee M. Clary ${ }^{1, * *}$

\begin{abstract}
The gryphaeid oyster Exogyra Say, 1820, is ubiquitous in Upper Cretaceous sediments in the southeastern United States. Like many oysters (Order Ostreida), Exogyra attached its shell to hard surfaces on the seafloor by means of cementation. Throughout its lifetime, Exogyra may preserve through bioimmuration the characteristics and even skeletal remains of substrate organisms, including mollusk shells, echinoids, and bryozoans. Exogyra costata of all sizes were collected from three different localities within upper Maastrichtian deposits in northeast Mississippi and their bioimmurations analyzed. Substrates were identified and classified to compare the three localities' substrate taxa in order to probe differences in benthic population structure. The results of this pilot study provide an overview of available surfaces on the Late Cretaceous seafloor on the eastern side of the Mississippi Embayment. The data suggest that taxonomic diversity among utilized substrates may increase from north to south, which corresponds to increasing depth from shallow marine to deeper sediments on the shelf.
\end{abstract}

Key words: Exogyra; oysters; bioimmuration; Cretaceous; Mississippi; Maastrichtian.

\section{RESUMEN}

La ostra Exogyra Say, 1820, de la familia Gryphaeidae es ubicua en sedimentos del Cretácico Superior en el sureste de los Estados Unidos de América. Al igual que muchas ostras (orden Ostreida), la Exogyra fija su valva en superficies duras del piso marino por medio de cementación. Durante su vida, la Exogyra puede preservar por medio de encostramiento las características, e incluso restos esqueletales, de organismos del substrato como moluscos, conchas, equinoides y briozoos. Ejemplares de Exogyra costata de diversos tamaños fueron colectados de depósitos del Maastrichtiano superior en tres diferentes localidades del noreste de Mississippi y se analizaron sus encostramientos. Los substratos fueron identificados y clasificados para comparar los taxones presentes en las tres localidades a fin de evaluar las diferencias en la estructura de las poblaciones bentónicas. Los resultados de este estudio piloto aportan información sobre las superficies disponibles en el piso marino del Cretácico Tardio en la porción oriental de la Bahía de Mississippi. Los datos sugieren que la diversidad taxonómica en los sustratos utilizados aumentaría de norte a sur, lo cual corresponde a un aumento en la profundidad de los sedimentos de marino somero profundo en la plataforma continental.

Palabras clave: Exogyra; ostras; encostramiento; Cretácico; Mississippi; Maastrichtiano.

\section{INTRODUCTION}

Oysters (Order Ostreida) are common and relatively diverse in Cretaceous and younger sediments in the Atlantic and Gulf Coastal Plain provinces of the United States (White, 1884; Stenzel, 1971). They are of considerable biostratigraphic utility as the shells' calcitic composition favors their preservation in a broad variety of sediment types (Cooper, 1992), and they exhibit regular successional speciation, or anagenesis (Stenzel, 1971). One of the most conspicuous fossils in the Upper Cretaceous of the coastal plain provinces is the gryphaeid oyster Exogyra Say, 1820. This characteristically thick-valved, gyriform, relatively deep subtidal oyster is an important and recurring element of epicontinental benthic assemblages at numerous locations around the globe (Stenzel, 1971; Paleobiology Database [PBDB], 2020), although Exogyra is primarily limited to the Atlantic basin and western Tethys (Malchus, 1996).

Oysters are sclerobionts that live epifaunally and cement their shells to rigid surfaces on the seafloor. The sundry assortment of durable materials composing the seafloor to which sclerobionts attach is collectively called cultch. The seafloor surfaces often consist of the accumulated debris of diverse skeletal macrofauna. Most sessile benthos have defenses to keep the larvae of other organisms from attaching to living individuals, therefore most sclerobionts like oysters attach to the hard, skeletal parts of dead organisms.

After larval settlement and attachment, the growing oyster reaches sufficient size where the attachment point on the cementing valve may preserve recognizable characteristics of the mollusk, echinoid, 
polychaete, bryozoan, or other object to which it was attached. It may retain part or even most of the substrate organism's skeletal remains if preservation is favorable. Diagnostic features of the substrate taxon can be preserved with varying degrees of resolution (e.g., Galtsoff, 1964), and occasionally with high fidelity, although this depends on the competence and durability of the substrate. The moldic mimic of the substrate at the attachment site on the oyster is a type of embedment structure (sensu Bertling et al., 2006) termed a bioimmuration (e.g., Taylor, 1990). When attachment and moldic overgrowth occur on skeletal cultch with a low preservation potential, such as that of aragonitic mollusks, the taxa preserved can be counted as present, where otherwise they may have been undocumented. Thus, high-resolution bioimmurations have the potential to reveal important information about the taxonomic composition of available substrates, providing an alternative and supplemental perspective of the benthos to skeletal and moldic preservation.

Attachment scar characteristics in Exogyra costata Say, 1820, were compared among three different localities within a late Maastrichtian (latest Cretaceous) interval in northeast Mississippi, USA. In particular, taxonomic composition of bioimmurations was analyzed for any differences or similarities among the sites or formations (or lithofacies therein). Differences in skeletal mineralogy and benthic ecology were also evaluated among the substrate taxa. This research probed whether differences existed in taphonomic processes between lithofacies and localities that could lead to understanding variations in benthic population structure.

\section{Exogyra ecology}

Exogyra Say (Ostreoida: Gryphaeidae) is a widespread oyster in Upper Cretaceous deposits of the North American coastal plain provinces (Stephenson, 1914; Lerman, 1965). The genus may extend as far back as the middle Cretaceous (Aptian-Cenomanian), depending on different interpretations of gryphaeid systematics (e.g., Malchus, 1996; Malchus and Aberhan, 1998). Jurassic and Early Cretaceous species formerly assigned to Exogyra globally are now placed in other genera, such as Nanogyra Beurlen and Aetostreon Bayle (Malchus and
Aberhan, 1998; Sha et al., 2002; Rubilar and Lazo, 2009; Koppka, 2015).

Exogyra is an extremely inequivalve oyster with a thick, deep, ponderous, gyriform left valve capped by a much smaller, shallower, flattened, opercular right valve (Figure 1). The oyster began life attached by its left valve, and it used a subcentrally located adductor muscle to manipulate the opercular upper right valve. As in nearly all oysters, attachment of the left valve by cementation to a hard or firm substrate was obligatory (Stenzel, 1971). Following settlement, Exogyra larvae cemented themselves to a suitable, stable, typically inert substrate upon which they developed and matured. Substrate fixation was solely for the successful survival of the early ontogenetic stages.

Survivorship of modern oyster larvae is increased on clean, elevated surfaces above potentially dysoxic and congestive seafloor sediment (Yonge, 1960; Bayne, 2017). The epibenthic success of settling meroplankton may be directed by a variety of biotic - both endogenous and exogenous-as well as abiotic physicochemical factors and cues (Bonar et al., 1990). Exogenous biological cues include microbial films on potential substrates that can influence successful settlement, attachment, and development. Survival of settling Exogyra larvae likely also partially depended on substrate properties, although assessing these factors in the fossil record is necessarily speculative; however, some factors may be indirectly determinable if diagenetic processes can be isolated. Two contributing agents to the success of larval settlement and attachment are frequently preserved in the fossil record: topography and texture. Substrate topography includes the coarser features of a mollusk shell, namely those external features associated with identification. Textural influences on settling larvae are related to the microscopic fabric of surfaces, features at a much smaller scale. There is some evidence in modern oysters that texture and/or topography influence the growth of the aforementioned microbial films and that such biofilms may in turn direct successful larval settlement and sclerobiont development (Agostini et al., 2017).

The maturing Exogyra reached a point at which its size, mass, and maturing morphology provided it with a means of stable, recumbent freedom from a position formerly fixed by its now proportionally smaller or decomposing substrate (Stenzel, 1971). Exogyra is also
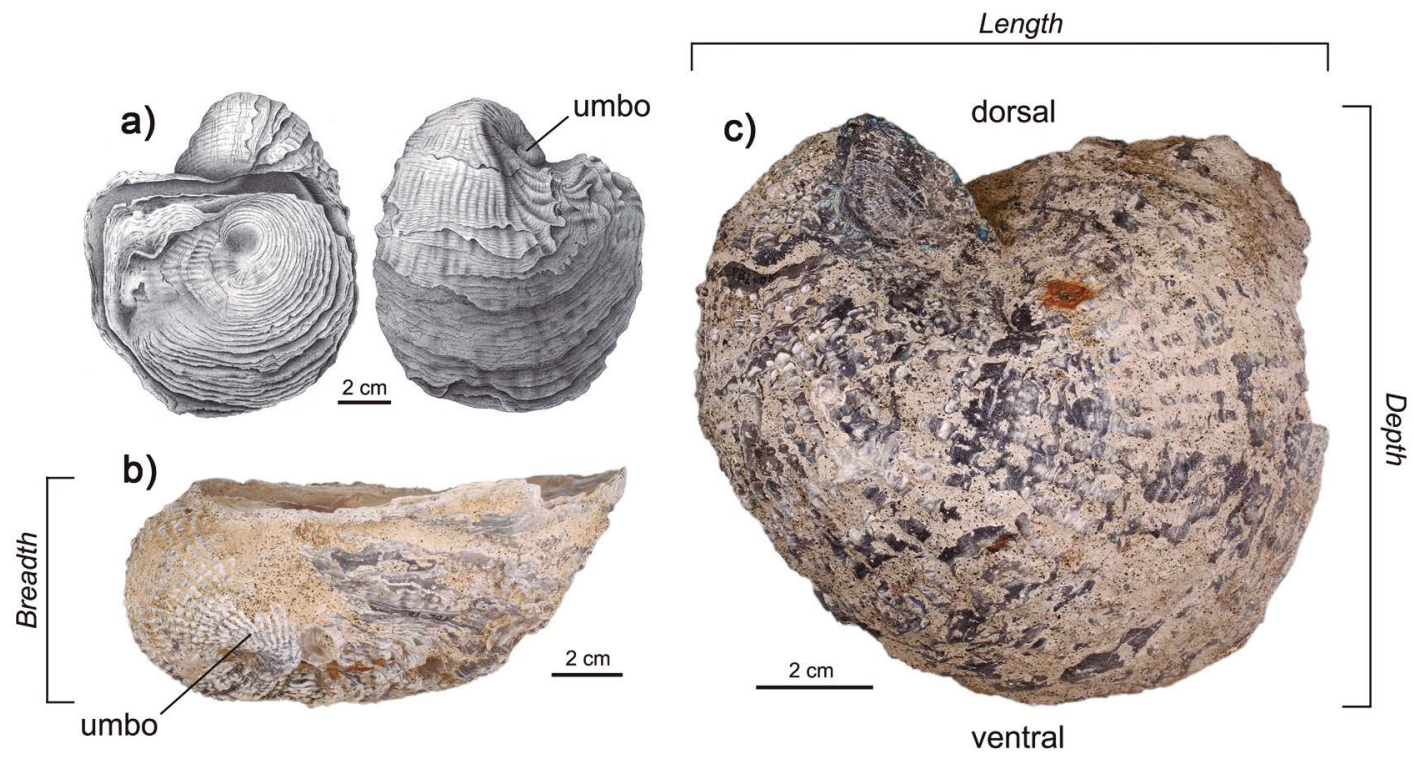

Figure 1. Exogyra costata Say in various aspects. a) Top (left) and bottom (right) views, from Whitfield (1885). b) Dorsal aspect of MMNS IP-9449.4, top directed upward ( $\approx$ living position); attachment scar directed downward and hidden from view. c) Bottom view of MMNS IP-9449.3, dorsal directed upward; umbo disfigured by attachment scar bearing mold of a Crassatella exterior. Measurements of left valves included anteroposterior Length, mediolateral Breadth, and dorsoventral Depth. Scale bar $=2 \mathrm{~cm}$. 
known to occur in small aggregates, but the incidence and degree of auto-attachment (i.e., conspecific attachment) varies among species and sedimentary environments (Lerman, 1965). Gryphaeid oysters such Exogyra experienced a major extinction at the end of the Cretaceous, likely related to their specialized shape and positional mode of life in the adult, that is, mostly unattached and reclining (Stanley, 1970; LaBarbera, 1981).

\section{Bioimmured substrates}

Oysters are among many unrelated groups of sedentary marine macroinvertebrates that attach to hard, stable substrates on the seafloor-from the intertidal zone to abyssal depths-in order to carry out their life cycles (Stenzel, 1971; Harper, 2012). Outcropping intertidal rock formations (including "beach rock" and offshore coral reefs) are familiar modern ecosystems abounding in attached organisms, many of them permanently encrusting rock or reef. In deeper water, particularly passive margin continental shelves, reef and rock are often scarce. In such offshore situations, refractory skeletal cultch accumulating on the seafloor becomes a valuable commodity for encrusting epibionts.

Bioimmuration is commonly preserved in the fossil record and has been documented in an assortment of unrelated encrusting organisms (Taylor, 1990). Oysters are among the most important bioimmuring groups in the Mesozoic and Cenozoic fossil record because they are widespread, have high growth rates, and preserve considerable substrate details in their attachment scars (Stenzel, 1971; Todd, 1993). Harper (1992, p. 45) proposed that, in oysters (modern or fossil), the high-fidelity molds are produced at the site of umbonal fixation by the "nucleation of calcareous cement crystallites" on to the substrate taxon.

Bioimmuration has been described, to varying degrees, in a wide variety of fossil oysters (Stenzel, 1971; Rohr and Boucot, 1989; Harper, 1992; Todd, 1993; Machalski, 1998; Harper, 2012), including the gryphaeid oyster Exogyra (Bishop, 1981; Griffin and Gibson, 1999). Machalski (1998) identified some of the skeletal substrates to which certain oysters attached in several hemipelagic facies in the Upper Jurassic of Poland. Seilacher et al. (1985) characterized morphotypic trends in these same Polish oysters, and Pliocene forms from southern Australia, noting a few of the substrate taxa. Peterson et al. (2009) mentioned bioimmured skeletal remains preserved in Albian Ceratostreon texanum (Roemer) ("Exogyra texana Roemer") from Texas, albeit with no subsequent documentation. Lerman (1965) and Bernstein (1986) briefly generalized that mollusks (including conspecific oysters), tubicolous polychaetes, and (questionably) plants functioned as substrates for Exogyra. In general, very few comprehensive assessments of skeletal faunal assemblages bioimmured by oysters have been published to date, and none for Exogyra.

\section{MATERIALS AND METHODS}

\section{Geological setting}

Left valves of Exogyra costata (and accompanying right valves, if present) were collected from upper Maastrichtian deposits occurring at three localities and two formations (approximating different lithofacies) in northeast Mississippi (Figure 2). From north to south, the sample sites lie roughly equidistant from one another along the eastern side of the Mississippi Embayment. The units and localities include the Owl Creek Formation near Ripley (OCR), the Prairie Bluff Formation at Houston (PBH), and the Prairie Bluff Formation in Starkville (PBS).

The OCR sample interval consists of an Exogyra bed estimated to lie 3-4 $\mathrm{m}$ above the lithologic base of the Owl Creek Formation about 4 $\mathrm{km}$ (2.5 mi) northeast of Ripley, Mississippi. The Owl Creek Formation is a dominantly siliciclastic lithofacies with variably calcareous clays and sands. Deposited on the inner shelf, this formation is characterized by exceptional aragonitic mollusk preservation. At OCR, the oyster bed lies in a fossiliferous, micaceous, slightly glauconitic, sandy dark, gray clay. The OCR interval is at the renowned Owl Creek type locality (Sohl, 1960, loc. 46).

To the south, the PBH sample interval is interpreted as the same Exogyra bed as at OCR, although lying within the adjoining Prairie Bluff Formation and closer to the mouth of the embayment and thus farther from shore. At this location, approximately $7.2 \mathrm{~km}(4.5 \mathrm{mi})$ north of Houston, Mississippi (Figure 2), the Prairie Bluff Formation is a fine-grained marl, or dirty chalk, with sandy, glauconitic intervals. Deposited on the middle shelf, the Prairie Bluff Formation exhibits very poor skeletal aragonitic mollusk preservation. However, macrofauna are partially preserved in phosphate-rich zones such as condensed beds and rockgrounds as a largely moldic assemblage. The PBH oyster bed is glauconitic and contains sparing amounts of fine quartz sand. This interval is interpreted to lie at least 2-3 meters above the base of the unit because of the local absence of characteristic sediments of the Ripley Formation. In Alabama, Bryan (1992) identified a similar Exogyra biostrome at least $2.5 \mathrm{~m}$ above the basal Prairie Bluff in Lowndes County. The sampled oyster beds at OCR and PBH thus probably represent a major, traceable surface across the eastern Gulf Coastal Plain.

Further south and even further from the embayment interior, in eastern Starkville, Mississippi (Figure 2), the PBS sample interval consists of Exogyra valves collected at the base of the Prairie Bluff Formation, which is a glauconitic marl with concentrations of medium to coarse, angular quartz sand. This depositional interval represents a transgressive systems tract exhibiting characteristics of a rockground (Bryan, 1992). Although the oyster beds at PBH and PBS are essentially of the same lithologies, they are interpreted as occurring in different parts of the formation.

The Upper Cretaceous Owl Creek and Prairie Bluff formations unconformably overlie the Ripley Formation and are truncated by the earliest Paleocene Clayton Formation (Figure 2). Between OCR and $\mathrm{PBH}$, in Union and Pontotoc counties, Mississippi, a transitional lithology of variably sandy marl lies between the Owl Creek and Prairie Bluff formations (Phillips, 2010); however, this lithofacies is not exposed at either locality.

The OCR and PBH oyster beds are considered here to be stratal equivalents and exhibit characteristics of a maximum flooding surface in a sedimentary cycle, specifically the UZAGC-5.0 transgressive sequence of Mancini et al. (1996). In middle marine shelf settings (and deeper), maximum flooding surfaces are characterized by a marked slowing of sedimentation (Catuneanu et al., 2011). The abundance of Exogyra at various growth stages in the thin OCR and PBH oyster beds, especially large, articulated valves, suggests a decrease in sediment supply during these intervals. Parras and Casadío (2005) reported such oyster bed demographics as consistent with maximum flooding surfaces in the Oligocene of Argentina. The Exogyra bed at OCR lies just below the beginning of the highstand systems tract as documented by Larina et al. (2016), which is consistent with the placement of a subjacent maximum flooding surface (Catuneanu et al., 2011). PBS lies at the base of the Prairie Bluff Formation and is interpreted as representing transgressive deposits of the same sequence, but further out on the shelf.

Locality data are available upon considered written request from Mississippi State University's Dunn-Seiler Museum (DSM) or the Mississippi Museum of Natural Science (MMNS).

\section{Sampling procedure}

Sampling of each interval consisted of collecting in situ and loose but stratigraphically traceable left valves representing at least half a 


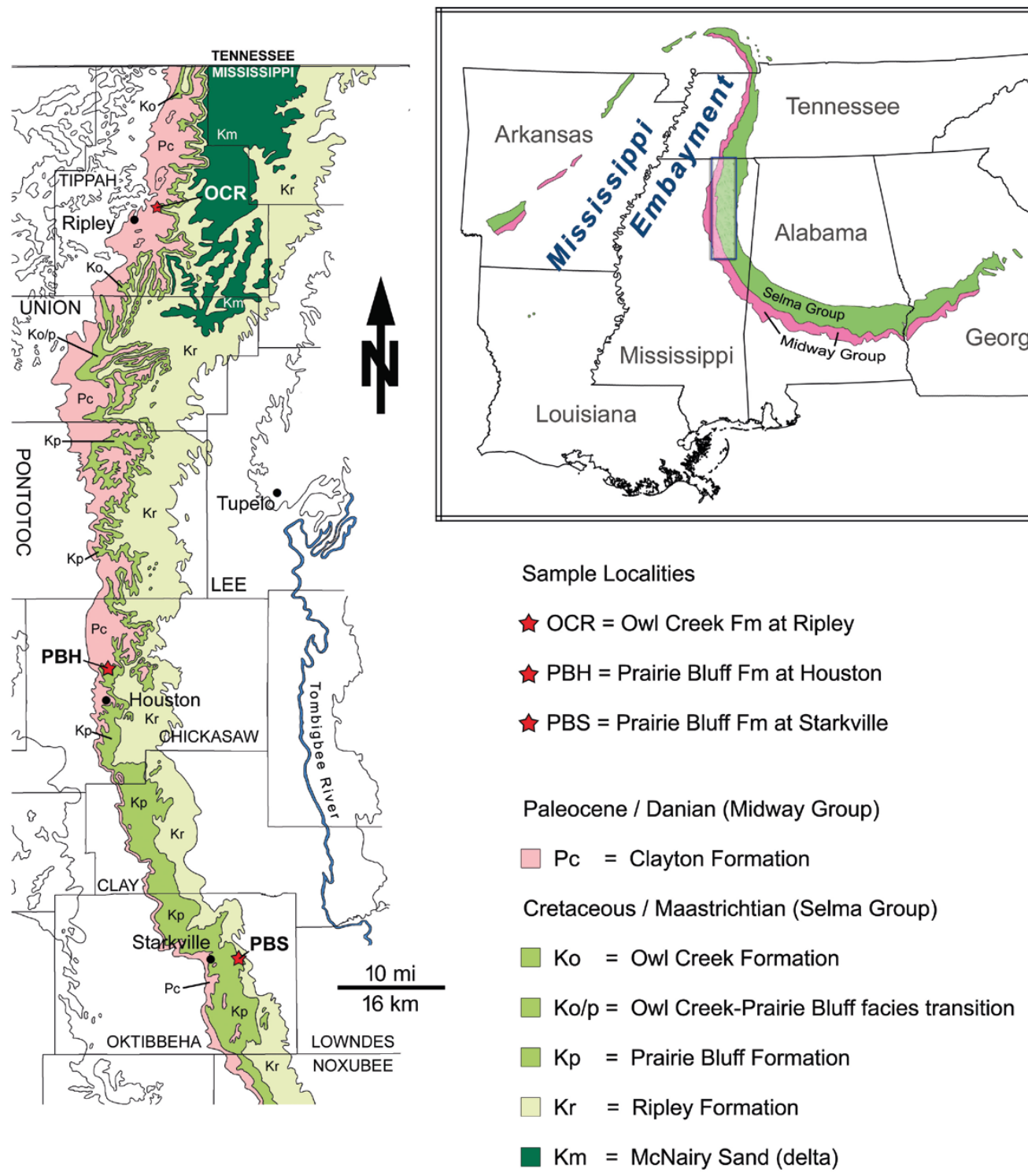

Figure 2. Geologic map of northeast Mississippi. Map shows outcropping Maastrichtian (and Danian) sediments in the study area. Localities (red stars) are relatively evenly distributed along the strike of the Prairie Bluff-Owl Creek facies complex. Inset map places the study area on the eastern side of the Mississippi Embayment. Mississippi graphic layers based on Bicker (1969); layers for U.S. regional inset based on Horton (2017).

valve (for measurement) with the entire attachment scar (for substrate identification). The great bulk of samples was collected in December 2017 with OCR samples supplemented by specimens similarly collected in March 2014. Purposive collection of Exogyra valves continued for at least two hours at each site, and each site presented different sampling challenges. Researchers attempted to sample throughout the outcrop and collect specimens of all sizes. Previously collected and reposited OCR material was later added to the analyses. Prior to analysis, shells were washed in water and mild detergent, with some specimens scrubbed repeatedly at the attachment scar to remove embedded, hardened matrix. Cleaned shells were measured and bioimmurations analyzed.

All specimens referred to herein, or otherwise utilized as part of this study, including bioimmured Exogyra valves and comparative material used for identification, are deposited and catalogued at the Mississippi Museum of Natural Science (MMNS) and the Dunn-Seiler Museum at Mississippi State University (MSU/DS).

\section{Specimen measurement}

Left valves of Exogyra were measured for anteroposterior length $(L)$, mediolateral breadth $(B)$, and dorsoventral depth (Figure 1; Table S1 of the Supplementary Material). Length and breadth were used to calculate the external surface area of left valves, which were modeled as hemispheres: $2 \pi r^{2}$, where $r=\left[\left(L_{\mathrm{Exo}} / 2\right)+B\right] / 2$, such that the ideal radius is estimated to lie between $L_{\mathrm{Exo}} / 2$ and $B$. Scar surface area was approximated by the product of scar length $(L)$ and width $(W)$, where $L$ is the maximum scar length (or greater dimension) and $W$ is the maximum scar width (or lesser dimension) roughly normal to $L$ (Figure 3 ). Basic statistics for sample length values are illustrated in a boxplot (Figure 4). Using measurable shells in each sample (Table S1 of the Supplementary Material), scar size (surface area) relative to shell size (external surface area) is presented as frequencies across classes (Figure 5). An outlier in the Owl Creek sample was not included: a relatively small shell with nearly its entire external surface involved in attachment.

Only those Exogyra collected individually at each outcrop were 

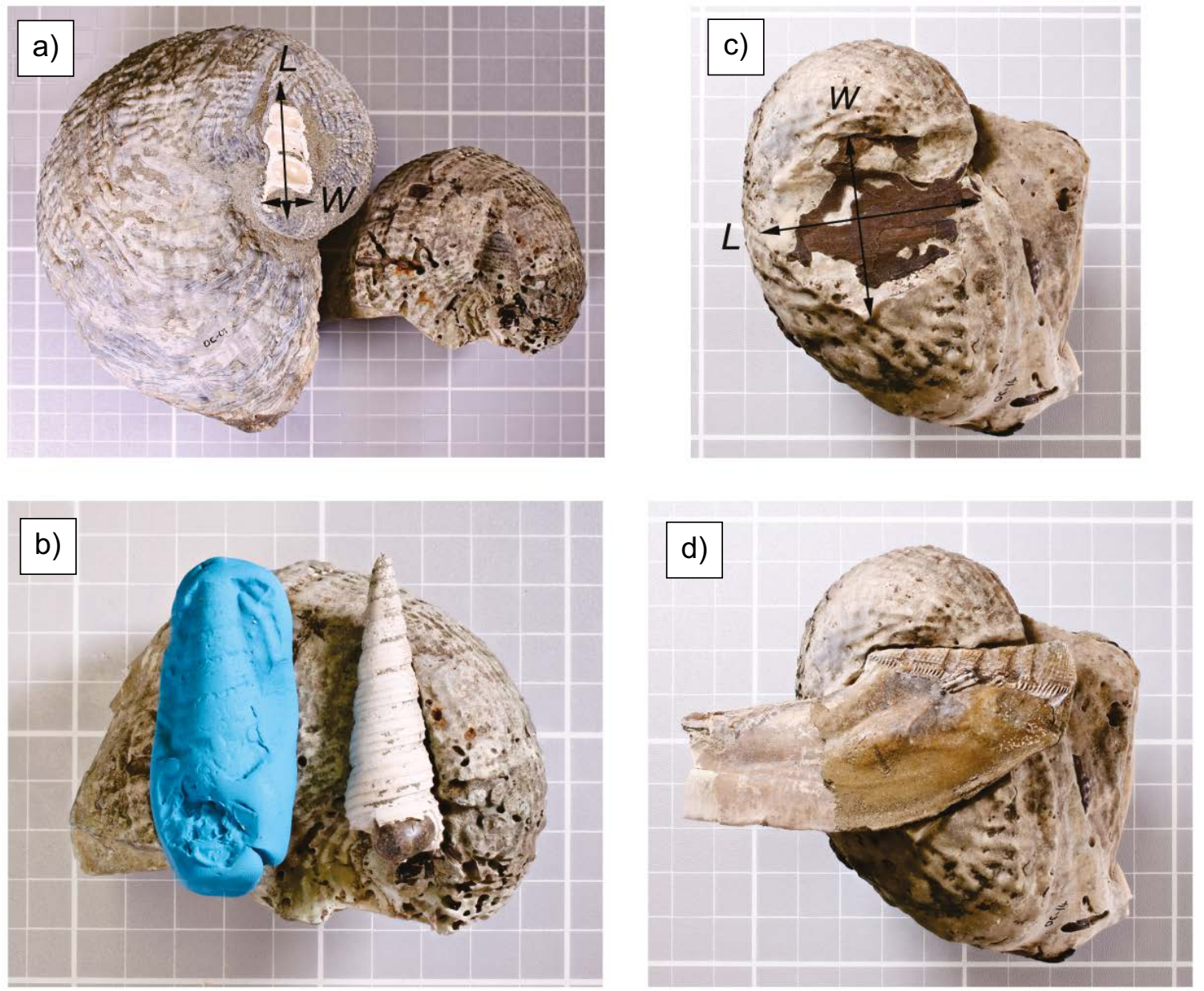

Figure 3. Examples of Exogyra and identified substrates from the Owl Creek type locality (OCR). a) MSU/DS OC-01 (left) and OC-23 (right) exhibiting portion of substrate and bioimmuration, respectively. In each case, Turritella is the substrate. b) MSU/DS OC-23 with a clay mold of the attachment scar. In this case, the substrate taxon was determinable to species-Turritella vertebroides Morton. A specimen of this gastropod from the same locality was placed in the scar for purposes of illustrating the match. c) MSU/DS OC-14 exhibiting a large, relatively flat attachment scar. d) A partial left valve of Gervilliopsis ensiformis (Conrad), which is common in this Exogyra bed, was placed in the scar to illustrate identification of the substrate. Scar surface area was calculated using maximum observed dimensions of length $(L)$ and width $(W)$. Grid squares $=\mathrm{cm}^{2}$.

measured. The Exogyra that were attached to the surfaces of the collected specimens were not included in the surface area versus scar area measurements, but they were included in the substrate analysis statistics.

\section{Substrate identification}

Exogyra substrates consisted dominantly of skeletal debris generated from the decomposition of calcitic and aragonitic macroinvertebrates, together with some phosphatic mollusk steinkerns, amorphous phosphatic pebbles, and yet-to-be identified objects. The mineralogical composition of the preserved co-occurring body fossils varies among the localities. The most important difference is that the Owl Creek macrofauna is known largely by aragonitic preservation and the Prairie Bluff fauna by calcitic taxa and steinkerns.

Identification of substrates was based on detailed examination of the attachment scars and comparing them to previously identified body fossils and molds in the MMNS Invertebrate Paleontology reference collection. The analysis was aided by the use of modeling clay to convert the impressions to positive relief, a dissecting scope for the smallest scars and fine taxon-specific details, and illustrated systematic descriptions of Upper Cretaceous macroinvertebrates from the Gulf and Atlantic coastal plains, including Weller (1907), Wade (1926), Stephenson $(1923,1941,1955)$, Sohl $(1960,1964)$, and Richards (1958, 1962). In addition, the faunal lists of Sohl and Koch (1983) for upper Maastrichtian sediments in the eastern Gulf Coastal Plain were useful in developing expectations about taxa reported from body-fossil samples. The following locality censuses from this USGS Open File Report were utilized: localities $42,43,44,45$, and 46 for the Ripley (OCR) vicinity, $65,66,67$, and 68 for Houston (PBH), and 80, 81, 82, 83, 84, 85, 87, and 88 for Starkville (PBS). The taxonomic composition of the Sohl and Koch (1983) samples is presented in Table S2 of the Supplementary Material. In a few cases, a portion of the substrate taxon remained in the attachment scar, making identifications considerably easier.

\section{Substrate classification}

Following identification, substrates were arranged into taxonomic groups, then classified according to their dominant benthic tier and skeletal mineralogy (Table 1, Figures 6-8). Seven major taxonomic groups were utilized among the localities: bivalves, gastropods, cephalopods, anthozoans, polychaetes, bryozoans, and echinoids (Table 1, Figure 6). Because phosphatic pebbles were utilized as a substrate in the Prairie Bluff samples, they were counted as a substrate 


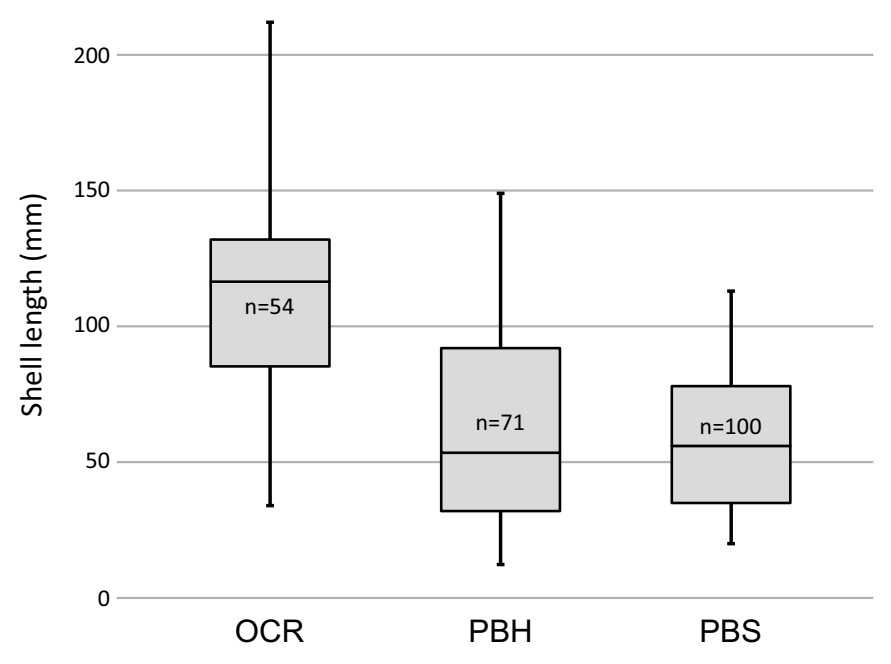

Figure 4. Boxplots of Exogyra length, by locality.

taxon in the comparisons (Figures 6, 8). Up to a third (17-34 \%) of the attachment scars were not included because of insufficient determination of mineralogical composition. Tiering, or the position of macroinvertebrates in relation to the surface of the seafloor, was defined for all applicable benthic taxa where the attachment scars were clearly definable (Table 1, Figure 7). The classification here is based largely on Stanley (1970, 2015), Bottjer (1981), Jablonski and Bottjer (1983), McClure and Bohonak (1995), and Scott and Claggett (2018); supplemental ecological information was gleaned from Fossilworks.org (Fossilworks: Gateway to the Paleobiology Database, 2013). Skeletal mineralogy was classified for each taxon as primarily calcite (including high- and low-Mg polymorphs), primarily aragonite, or mixed (Table 1, Figure 8). Chave $(1954,1962)$ and Skinner and Jahren (2003) were the principal sources for mineralogical classification of taxa in the present samples.

Only supportive substrates were counted. There is always a competition for space on good substrate, and oyster larvae may land on (or near) established sclerobionts and ultimately overgrow them. Sclerobionts that are less substantial than the maturing Exogyra will become trapped between the oyster and the substrate, which is the functional support for both encrusters. Although structurally unsupportive to a large sclerobiont like Exogyra, Taylor and Todd (1990) indicated that the entombment of smaller encrusting organisms by larger ones is important in the preservation of more fragile, softer-bodied epifauna.

\section{Diversity and similarity}

Population diversity and similarity were measured in order to compare the taxonomic composition of the substrate taxa. The Simpson diversity (Table 1$)$ is calculated as $1-\left(\sum n(n-1) / N(N-1)\right)$, where $n$ is the quantity in each class (taxon) and $N$ is the total number of usable specimens in the sample. This index considers what the relative abundance of individual groups (taxa) contribute to diversity beyond simple presence. Although apparent (numerical) diversity is highest among the Starkville (PBS) substrates (at least by one taxon), Simpson's index reveals a slightly greater substrate diversity in the Houston sample $(\mathrm{PBH})$. Similarity indices were calculated between paired samples. Among the chosen similarity evaluations, the OCR and PBH samples seem to be consistently the most taxonomically similar.

Simpson and Jaccard similarities were also assessed between samples (Table 2). Simpson similarity is a comparison of the shared taxonomic composition relative to the smallest sample, whereas Jaccard considers the same value relative to the sum of both samples.

\section{DISCUSSION}

Modern oysters (Order Ostreoida) attach to a broad variety of substrates; larval success requires a clean, hard (or firm) surface. Utilized surfaces include rocks, rigid marsh vegetation, submerged deadwood, mangrove roots, and mollusk shells, plus a number of manmade, synthetic materials littering the shoreline or floating offshore. The most familiar oyster species-the true oysters (Ostrea, Crassostrea, and related genera)-inhabit intertidal or shallow subtidal zones, particularly estuarine settings, where they typically live gregariously

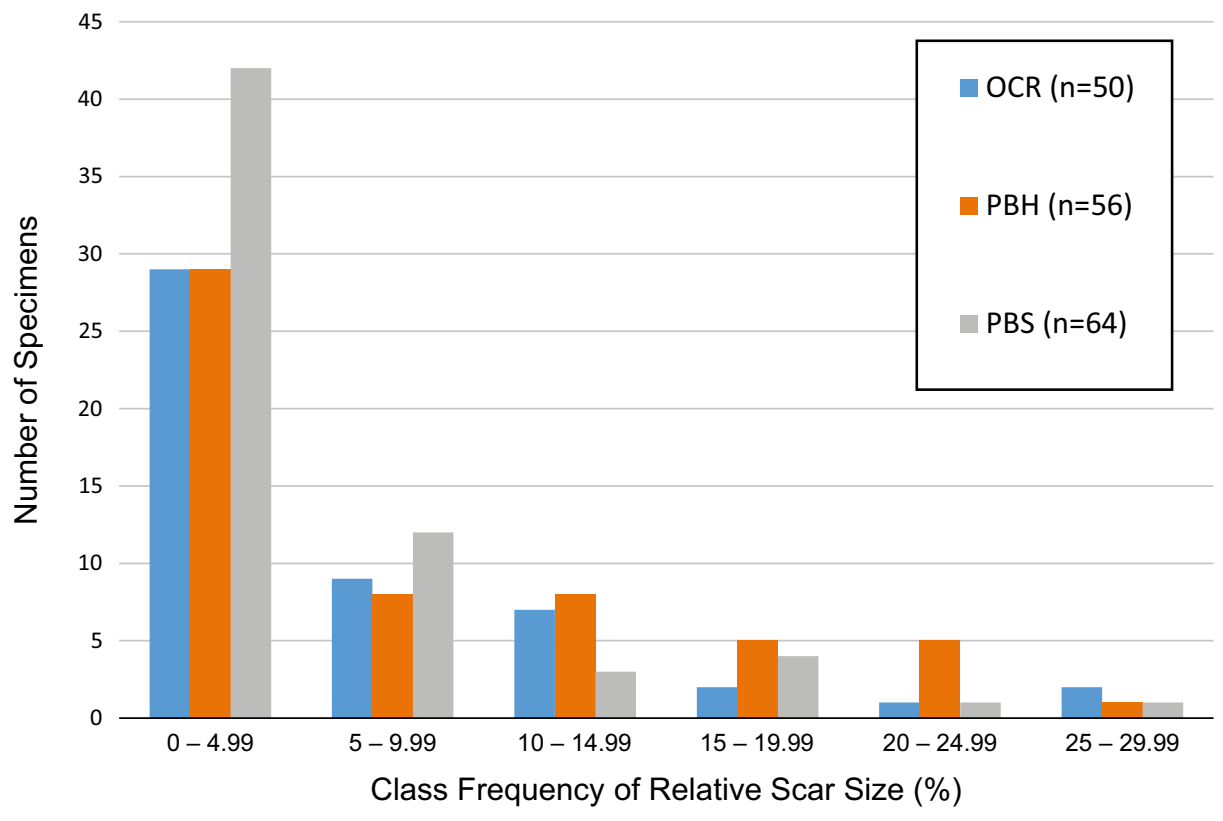

Figure 5. Exogyra relative scar size grouped into frequency classes. 
Table 1. Grouped substrate taxa and assemblage diversity. Shaded quantities represent unidentified fossils within each group and were not treated as discrete taxonomic classes nor considered in numerical diversity and similarity analyses (Table 2). The Simpson diversity is calculated as $1-\left[\sum n(n-1) / N(N-1)\right]$.

\begin{tabular}{|c|c|c|c|c|c|c|}
\hline & Identified Substrate Taxa & Mineralogy & Benthic Tier & OCR & PBH & PBS \\
\hline \multirow{17}{*}{ BIVALVES } & Exogyra costata & Calcite (low Mg) & Epifaunal & 18 & 17 & 30 \\
\hline & Pycnodonte vesicularis & Calcite (low Mg) & Epifaunal & 0 & 0 & 2 \\
\hline & Ambigostrea tecticosta & Calcite (low Mg) & Epifaunal & 0 & 1 & 0 \\
\hline & Agerostrea falcata & Calcite (low Mg) & Epifaunal & 0 & 0 & 1 \\
\hline & Oyster indet. & Calcite (low Mg) & Epifaunal & 0 & 0 & 2 \\
\hline & Anomia perlintea & Mixed & Epifaunal & 0 & 1 & 0 \\
\hline & Gervilliopsis ensiformis & Aragonite & Epifaunal & 9 & 8 & 0 \\
\hline & Pinna laqueata & Aragonite & Semi-Infaunal & 2 & 0 & 0 \\
\hline & Cucullaea capax & Aragonite & Infaunal & 4 & 1 & 3 \\
\hline & Arcidae: cf. Arca rostellata & Aragonite & Epifaunal & 0 & 0 & 0 \\
\hline & Nemodon sp. & Aragonite & Epifaunal & 0 & 0 & 1 \\
\hline & Arcoida indet. & Aragonite & & 0 & 0 & 4 \\
\hline & Aphrodina tippana & Aragonite & Infaunal & 0 & 0 & 1 \\
\hline & Crassatella vadosa & Aragonite & Shallow Infaunal & 1 & 1 & 0 \\
\hline & Cyprimeria cf. alta & Aragonite & Infaunal & 1 & 0 & 0 \\
\hline & Trachycardiumsp. & Aragonite & Infaunal & 0 & 1 & 0 \\
\hline & Bivalve, indet. & & & 1 & 4 & 3 \\
\hline \multirow[t]{7}{*}{ GASTROPODS } & Calliomphalus sp. & Aragonite & Epifaunal & 0 & 0 & 1 \\
\hline & Turritella vertebroides & Aragonite & Semi-Infaunal & 7 & 0 & 1 \\
\hline & Volutomorpha sp. & Aragonite & Epifaunal & 0 & 2 & 0 \\
\hline & Xenophora leprosa & Aragonite & Epifaunal & 0 & 1 & 0 \\
\hline & Naticidae indet. & Aragonite & Semi-Infaunal & 0 & 0 & 1 \\
\hline & Pyropsis sp. & Aragonite & Epifaunal & 0 & 0 & 1 \\
\hline & Gastropod indet. & Aragonite & & 1 & 4 & 2 \\
\hline \multirow[t]{4}{*}{ CEPHALOPODS } & Sphenodiscus sp. & Aragonite & Nektonic & 0 & 1 & 0 \\
\hline & Baculitidae indet. & Aragonite & Nektonic & 0 & 0 & 1 \\
\hline & Belemnitella americana & Calcite (low-Mg) & Nektonic & 0 & 0 & 1 \\
\hline & Mollusk indet. & & & 1 & 1 & 2 \\
\hline \multirow[t]{2}{*}{ ANTHOZOANS } & Pennatulacea: Virgulariidae & Calcite (high-Mg)* & Epifaunal & 1 & 0 & 2 \\
\hline & Alcyonacea: Scleraxonia & Calcite (high-Mg)* & Epifaunal & 0 & 3 & 0 \\
\hline POLYCHAETES & Polychaeta: Serpulidae & Mixed & Epifaunal & 0 & 4 & 9 \\
\hline BRYOZOANS & Bryozoan indet., erect form & Calcite (high-Mg)* & Epifaunal & 1 & 1 & 0 \\
\hline \multirow{7}{*}{ ECHINOIDS } & Echinoid, regular indet. & Calcite (high-Mg)* & Epifaunal & 0 & 1 & 1 \\
\hline & \multirow{2}{*}{\multicolumn{2}{|c|}{$\begin{array}{l}\text { Amorphous phosphatized pebbles/masses } \\
\text { Unidentified objects of various shapes and sizes }\end{array}$}} & & 0 & 2 & 3 \\
\hline & & & & 7 & 17 & 29 \\
\hline & \multicolumn{3}{|c|}{ Total number of specimens in sample $=$} & 54 & 71 & 101 \\
\hline & \multicolumn{3}{|c|}{ Number of specimens in recognized classes $(\operatorname{taxa})=$} & 44 & 45 & 63 \\
\hline & \multirow{2}{*}{\multicolumn{3}{|c|}{$\begin{array}{r}\text { Numerical diversity }= \\
\text { Simpson diversity }=\end{array}$}} & 9 & 16 & 17 \\
\hline & & & & 0.77 & 0.83 & 0.75 \\
\hline
\end{tabular}

${ }^{\star}$ The skeletal calcite of organisms that precipitate high magnesium (high-Mg) phases is often diagenetically altered to a low-Mg calcite.

on mudflats (Yonge, 1960; Galtsoff, 1964). Exogyra, however, like most familiar gryphaeids of the Gulf and Atlantic Coastal Plain, is primarily found in shelf marls and chalks, offshore in the deep subtidal zone.

Cultch objects utilized by Exogyra as substrate ranged in size from a few millimeters to several centimeters (Table $S 1$ of the Supplementary Material), some fragments just large enough to provide a solid purchase for settling larvae and cementing spat. The Cretaceous cultch available to settling and developing Exogyra larvae during the deposition of the Prairie Bluff and Owl Creek formations consisted of varied skeletal debris generated dominantly by macroinvertebrates and, in the case of the even deeper water Prairie Bluff Formation, phosphate pebbles (amorphous pebbles and mollusk steinkerns).

Generally, Exogyra valves in the OCR sample attained a larger adult size and exhibited a greater range of sizes than the Prairie Bluff samples, which were similar in size distribution (Figure 4). Fewer shells larger than $100 \mathrm{~mm}$ in the PBH and PBS samples may be a result of more significant bioerosion in these samples. This is not unexpected for PBS as it was collected from the base of the Prairie Bluff Formation, which is a transgressive surface with objects exposed for extended periods on the seafloor and often includes reworked fossils. An alternative explanation for fewer larger individuals at the Starkville site is its location-near an apartment complex where souvenir hunters might reside. Another possibility involves a combination of collecting and preservational biases. Our protocol necessitated the need for relatively complete shells, and we estimate the Exogyra-bearing bed at the Starkville locality to have been exposed to weathering longer than the other two localities, which may have hindered preservation and retrieval of larger shells. 

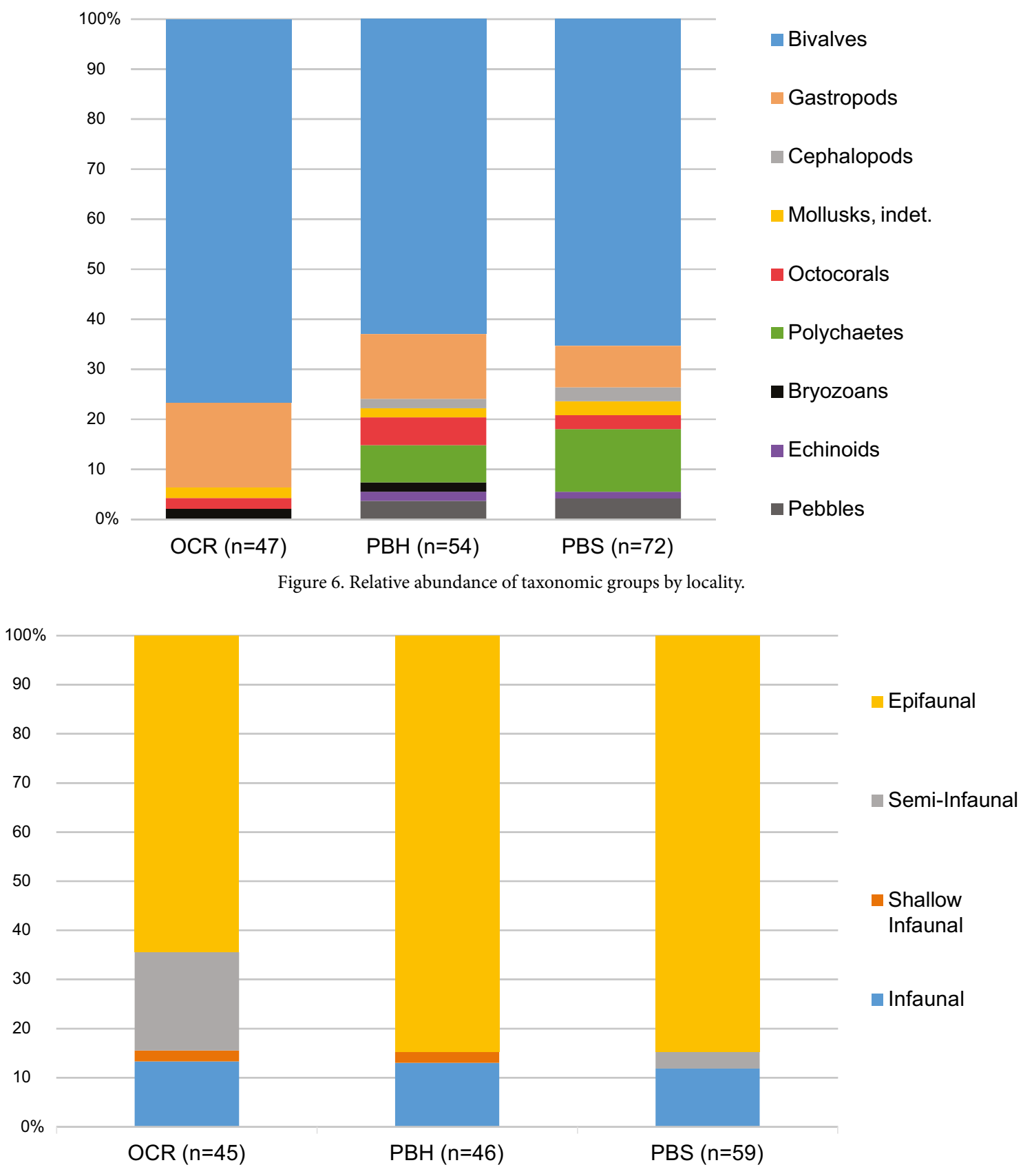

Figure 7. Benthic tiering among mollusks by locality.

\section{Preservational bias}

An obvious inherent preservational bias exists among all localities resulting from the along-strike facies changes representing different locations and depositional environments within the larger depocenter, the Mississippi Embayment. The decreasing siliciclastic content from north to south (i.e., OCR to PBS, Figure 2) results in a corresponding increase in carbonate content. As aragonite is not preserved or only poorly preserved in the more alkaline carbonates to the south, the fauna of the Prairie Bluff Formation (PBH and PBS) is a moldic one. The OCR's shelly assemblage represents a different taphonomic history than the moldic assemblages of PBH and PBS.

When mollusk shells were utilized as substrates, it was clear that OCR Exogyra consistently attached to shells and not steinkerns, but this was not always clear in the Prairie Bluff samples. In some specimens at
PBH and PBS, the substrate, a mollusk steinkern, remained partially intact at the attachment site. Since removal of the steinkern would have damaged the Exogyra, it could not always be determined whether $\mathrm{PBH}$ and PBS Exogyra attached to shells or steinkerns. However, in the vast majority of unobstructed Prairie Bluff attachment scars where mollusks were clearly the substrate, Exogyra was attached to the original shell. In addition, at least one of the PBS Exogyra contained a gastropod steinkern (Figure 9); a matrix-filled gap between the moldic mollusk and the attachment scar suggests that the oyster was originally attached to shell. Although not explored in this research, the observation can provide information on individual components' ages and the timeaveraged nature of the shelly substrata.

Substrates with calcitic, mixed, and phosphatic mineralogies were increasingly utilized by Exogyra with increasing depth along the sample 


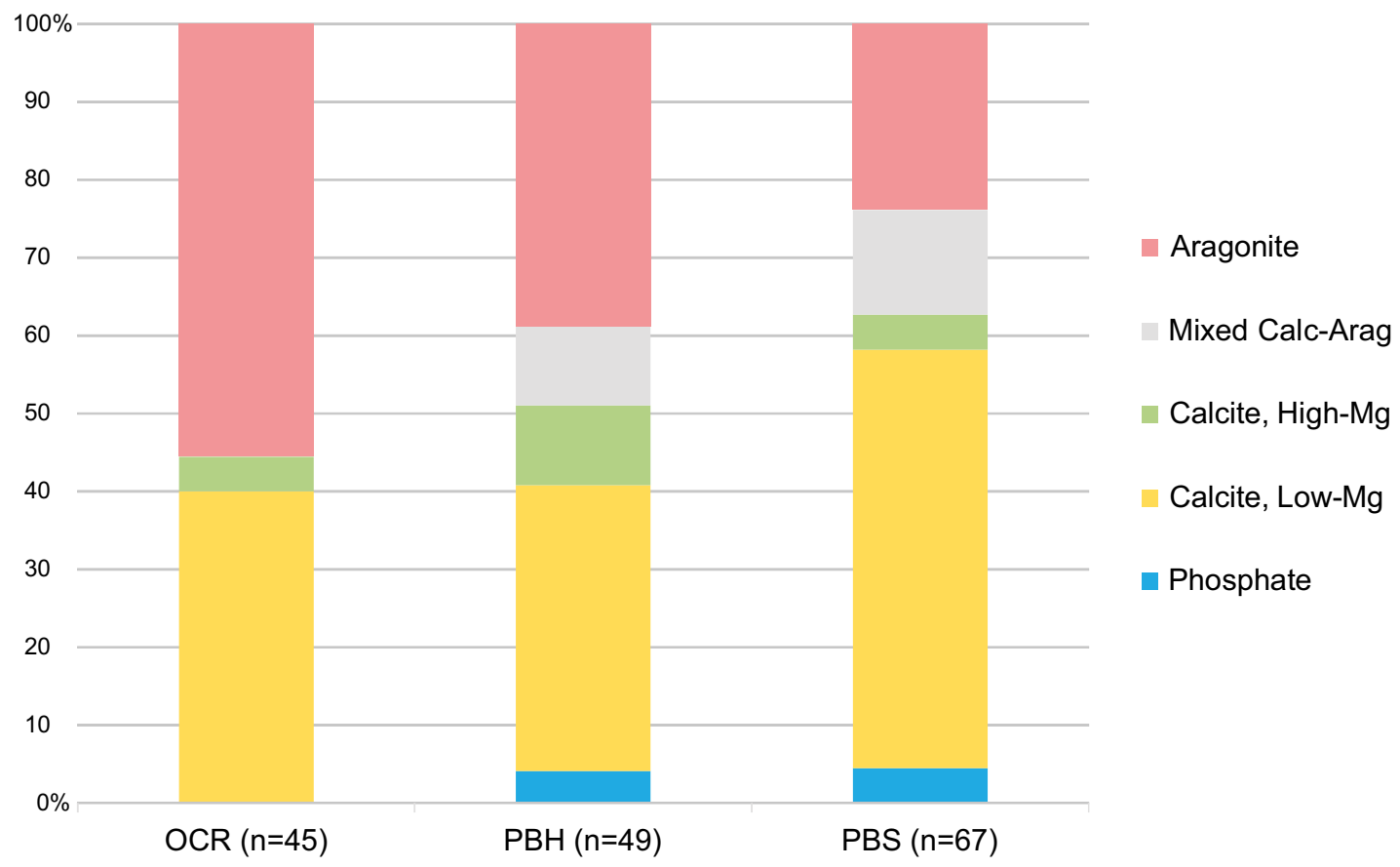

Figure 8. Skeletal mineralogy by locality.

transect from north to south (Figure 8). This enrichment in calcitic debris in the PBS sample interval might be expected as it is a condensed bed associated with a transgressive surface in alkaline sediments, which works against the long-term persistence of aragonitic skeletons. However, the generally poorer preservation of aragonitic taxa (which otherwise contain greater molluscan biodiversity) over non-aragonitic taxa in the Prairie Bluff Formation (present samples included) does not seem consistent with the higher substrate diversity observed (Figure 6). Although the taxonomic diversity of utilized Exogyra substrates is higher in the Prairie Bluff samples, Bryan (1992) described the same deep-water interval (in Alabama) represented by the PBS sample as having generally low biological diversity. It appears diversity of ideal substrates for Exogyra colonization would not necessarily reflect or necessitate biological diversity of skeletal benthos in general.

\section{Bioimmurations}

At all localities and in most specimens, the attachment scar is small relative to shell size ( $<10-15 \%$ of surface area), with fewer shells having proportionally large scars (Figure 5). Lerman (1965) noted that the larger attachment scars are found more in cases of auto-attachment (clustering individuals) than in fixation to most other substrates. In addition, Exogyra costata has a greater incidence of larger scars than its older congeners, E. ponderosa Roemer, 1849, and E. cancellata Stephenson, 1914, at least modally among size classes (Lerman, 1965).

Only two previous reports focused on organisms bioimmured by Exogyra, both specifically involving E. costata. Bishop (1981) described a lobster, Linuparus canadensis (Whiteaves), bioimmured by this oyster in the early Maastrichtian Coon Creek beds (Ripley Formation) of Union County, Mississippi. In a brief note, Griffin and Gibson (1999) reported the occurrence of a variety of unspecified mollusks and a "tube-shaped" organism as substrates for E. costata at an approximately coeval level in the Coon Creek of Tennessee.

In the present study, attachment scars and substrates were identifiable with surprising frequency and specificity (Table S1 of the Supplementary Material, Figure 6). This provided a different perspec- tive of taxonomic composition of the late Maastrichtian seafloor on the eastern side of the Mississippi Embayment. The substrates recorded in the attachment scars of Exogyra dominantly represent the accumulated exoskeletal remains of dead and decaying mollusks and other organisms. Attachment to living substrates is not suspected for Exogyra, even in instances of auto-attachment, but this assertion is beyond the scope of the present study.

There were various reasons bioimmured substrates could not be identified among the moldic scars. Small attachment scars and eroded umbonal regions frequently contained insufficient information. Large, well-developed, uneroded scar molds were typically easier to identify, albeit occasionally problematic when the molds conveyed a featureless or amorphous surface. Scar impressions in the PBH and PBS samples were occasionally impacted with lithified or cemented matrix that would have required additional preparation skill and time. Identifications were also limited by the skills of the authors.

\section{Substrate diversity and similarity}

Although apparent (numerical) diversity is highest among the Starkville (PBS) substrates (at least by one taxon), Simpson's index, based on proportional representation among individual taxa, reveals a slightly greater substrate diversity in the Prairie Bluff sample from Houston (PBH) (Table 1). The data suggest that the taxonomic diversity among substrates generally increases from north to south (Figures 2,6), along outcrop strike and with a major lithofacies change that is equivalent to increasing depth and distance from shore, i.e., from shallow marine sediments under coastal influence (Owl Creek Formation) to deeper, more calcareous sediments on the shelf (Prairie Bluff Formation).

The greater similarity in species composition exhibited between OCR and PBH is demonstrated in both the Simpson and Jaccard indices (Table 2). Although the least amount of similarity between the most distant assemblages (OCR and PBS) might be predicted, this was not the case, at least not as conveyed by the Simpson formula and if absence is considered. However, this greater similarity is at least par- 
Table 2. Sample similarity. The Owl Creek (OCR), Prairie Bluff Landfill (PBH), and Starkville (PBS) samples were compared to evaluate assemblage similarity.

\begin{tabular}{|c|c|c|c|}
\hline & OCR-PBH & PBH-PBS & PBS-OCR \\
\hline Simpson $=$ & $56 \%$ & $31 \%$ & $44 \%$ \\
\hline \multicolumn{4}{|c|}{ S/LConsiders the shared taxa relative to the smallest sample. } \\
\hline \multicolumn{4}{|c|}{$S /(x+y-S)$ Considers the shared taxa relative to the total of both samples } \\
\hline $\mathbf{P}+\mathbf{A}=$ & 15 & 7 & 11 \\
\hline \multicolumn{4}{|c|}{ Similarity based on both present $(\mathrm{P})$ and absent $(\mathrm{A})$ taxa. } \\
\hline$S=$ & 5 & 5 & 4 \\
\hline \multicolumn{4}{|c|}{ Taxa in common between assemblages. } \\
\hline $\mathrm{L}=$ & 9 & 16 & 9 \\
\hline \multicolumn{4}{|c|}{ Number of taxa in least diverse assemblage. } \\
\hline & OCR & PBH & PBS \\
\hline$x, y=$ & 9 & 16 & 17 \\
\hline \multicolumn{4}{|c|}{ Basic numerical diversity (Table 1 ). } \\
\hline \multicolumn{4}{|c|}{$\begin{array}{l}x=\text { Total number of taxa in sample \#1. } \\
y=\text { Total number of taxa in sample \#2. }\end{array}$} \\
\hline
\end{tabular}

tially inflated because OCR has the smallest sample and PBS exhibits the greatest numerical diversity. A more accurate comparison, based on the numerical diversity of both samples, is the Jaccard index. If an absent taxon is considered a similarity between samples, then OCR and $\mathrm{PBH}$ are the most similar in this regard, too.

Mollusks constitute the commonest macroinvertebrate group represented in the skeletal and moldic faunas locally (e.g., Sohl and Koch, 1983), and they are likewise the commonest substrate for Exogyra (Figure 6). Bivalves dominate all substrate assemblage samples as identified from attachment scars but particularly the Owl Creek sample, where shells of Gervilliopsis and Exogyra make up the commoner substrates. The small, thin-shelled ark shells Nemodon eufaulensis (Gabb) and Arca rostellata Morton, absent in the Sohl and Koch (1983) samples from the Starkville vicinity, were captured in several Exogyra bioimmurations at PBS (Table S2 of the Supplementary Material). Anomia perlineata Wade, Trachycardium eufaulense (Conrad), and Gervilliopsis ensiformis (Conrad) were absent from body-fossil data collected in the Houston vicinity (Sohl and Koch, 1983) but present in Exogyra attachment scars. All these species are either epifaunal or shallow infaunal suspension feeders with relatively thin aragonitic shells, except for Gervilliopsis, which has a thick shell. The lack of body fossils for the thin-shelled aragonitic clams is not surprising given their preservation vulnerability over long exposure periods on the seafloor. Thus, the skeletal remains of some epifaunal organisms persist long enough to provide substrate for maturing Exogyra, although perhaps not long enough for body fossil preservation. Many attachment scars suggest fixture to simple, mostly featureless convex or concave surfaces suggestive of bivalves or portions thereof.

In the present study, independently living Exogyra were more common than clusters, although conspecific attachment was not uncommon. The greatest number of aggregates were observed at $\mathrm{PBH}$ where several uncollected clusters were observed embedded in the outcrop. Several large, mature valves from PBS exhibited multiple encrusting small, even tiny, Exogyra. In these cases, the attached individuals were often the same approximate size, suggesting either single spawning and settling events or a possible maximum size beyond which smaller encrusting individuals did not mature.

Following bivalves, gastropods (Figure 9) contribute heavily to substrate assemblages in the Owl Creek and Prairie Bluff Houston samples, with a slight reduction in the Prairie Bluff Starkville sample. As common as ammonites are in the Owl Creek Formation (e.g., Kennedy and Cobban, 2000), it is remarkable that not a single specimen was revealed in the OCR scar sample. Cephalopods were noted in scars in both Prairie Bluff samples, but such occurrences were rare.

Octocoral substrates were utilized at all sites, which is not surprising given that body fossils of this group are encountered with some regularity in Upper Cretaceous marl facies in the Gulf Coastal Plain (Phillips, personal observation). The calcified and variably preserved axes of sea pens (Pennatulacea) and gorgonians (Gorgonacea) functioned as attachment sites for settling Exogyra larvae. Attachment to elongate calcified objects, like sea pen axes and echinoid spines, is not uncommon in the Prairie Bluff Formation; these have been found preserved within the attachment scars of Exogyra costata. In addition to sea pens, several Exogyra scars among the current samples exhibit impressions suspected to be gorgonian axial skeletons. Calcareous gorgonian axes from the Prairie Bluff Formation are narrow, elongate, subcylindrical, occasionally branching bodies ostensibly formed by

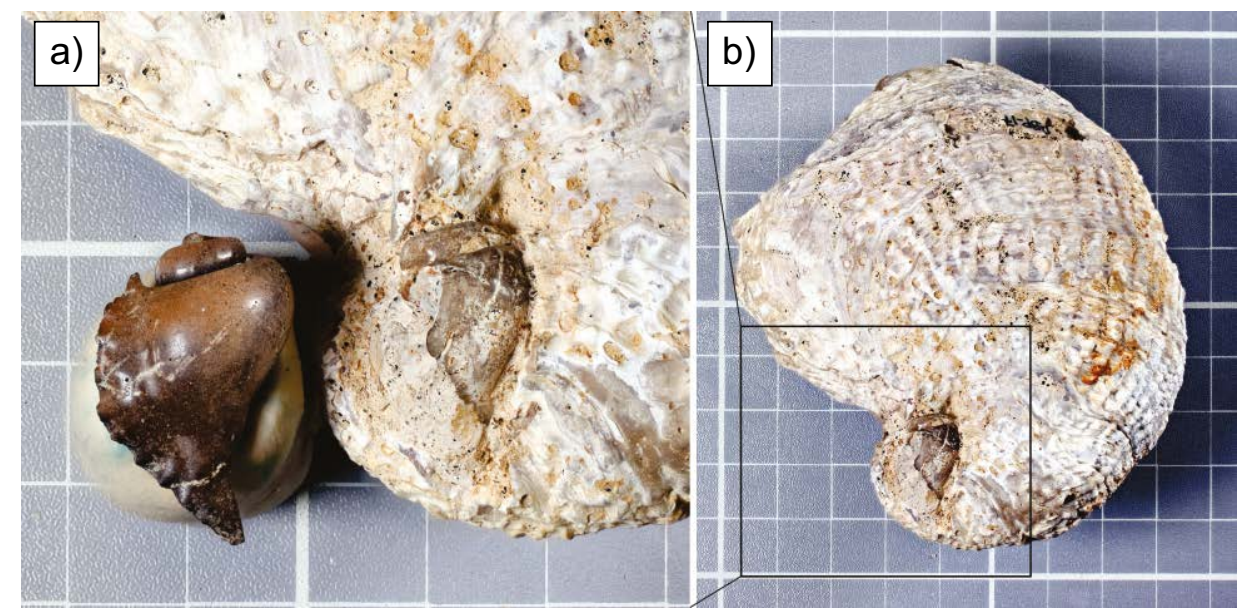

Figure 9. Exogyra attachment to a gastropod. a) Steinkerns of the tudiclid gastropod Pyropsis Conrad-free (left, MMNS IP-8432.01) and encrusted by Exogyra (right, MMNS IP-9450.06). b) By this size, Exogyra had assumed a free-resting position on the seafloor and is no longer stabilized by the now smaller mollusk substrate, which in this case is partially overgrown at the attachment site. Grid squares $=1 \mathrm{~cm}$. 
the fusion of coarsely anastomosing cords, which would produce a mold consistent with several impressions observed among the samples (Figure 10).

Although unpublished from the Cretaceous of Mississippi, octocoral fossils have been described from the state's Paleogene sediments (Hickson, 1938; Kocurko and Kocurko, 1992) and reported from Cretaceous deposits across the North Atlantic (Nielsen, 1914; Williams, 1999). The Virgulariidae (Pennatulacea) are the most commonly reported sea pen family from the Cretaceous (Williams, 1999), with sea pen macrofossils consisting commonly of fragmentary axes that form the stalks of the colonies, although the microfossils (spicules) are most often reported. The greater number of Mississippi Maastrichtian axes in the MMNS collection compare well to the Virgulariidae (G.C. Williams, personal communication, 2008), such as the forms illustrated by Nielsen (1917) and Reich and Kutscher (2011). Both scleraxonian and holaxonian gorgonaceans are known in the Cretaceous fossil record from calcified axes, but the precise identities of the Maastrichtian specimens from Mississippi are currently undetermined. Whether octocoral axes were encrusted before or after falling from an erect, living or early postmortem position remains to be determined, but our initial impression is Exogyra attachment to late postmortem axes.

Griffin and Gibson (1999) summarized the occurrence of mollusk shells and a "tube-shaped" organism as substrates for E. costata in the Coon Creek Formation (early Maastrichtian) in adjoining Tennessee and speculated that either sponges or octocorals were the most likely substrate. No sponges were identified in the current samples, although they may exist among the unattributed bioimmurations.

Polychaete tubes are sinuous, subcylindrical structures, $\sim 1-5 \mathrm{~mm}$ in diameter, commonly encrusting Exogyra at all localities. In fact, most polychaete tubes functioning as Exogyra substrates had already attached to other Exogyra. The PBS sample exhibits the greatest incidence of attachment to polychaete tubes. Although polychaete tubes were observed on Owl Creek Exogyra, none of the attachment scars at OCR exhibited morphology consistent with such structures.

Bryozoans were utilized as substrates, but only the erect forms were counted as structural supports. Where encrusting, stoloniferous, or other low-growing, film-like zoaria were present in an Exogyra attachment scar, they were invariably attached to other Exogyra, and classified as auto-attachment. This is because structural support for the maturing oyster spat almost certainly came from the larger object.

In the present samples, echinoid spines occasionally provided substrate for encrusting Exogyra, but only in the Prairie Bluff Formation. Spines are rather small targets on the seafloor for settling larvae of meroplanktonic sclerobionts, but a single regular echinoid (Cidaroida) produces many stout spines. The lack of scar impressions showing attachment to echinoid tests is discussed further below.

Amorphous phosphatic pebbles, although identified among the Prairie Bluff substrates, were not utilized by Owl Creek oysters. This is not surprising given the scarcity of such clasts at OCR compared to the Prairie Bluff sites. Although amorphous pebbles were utilized on

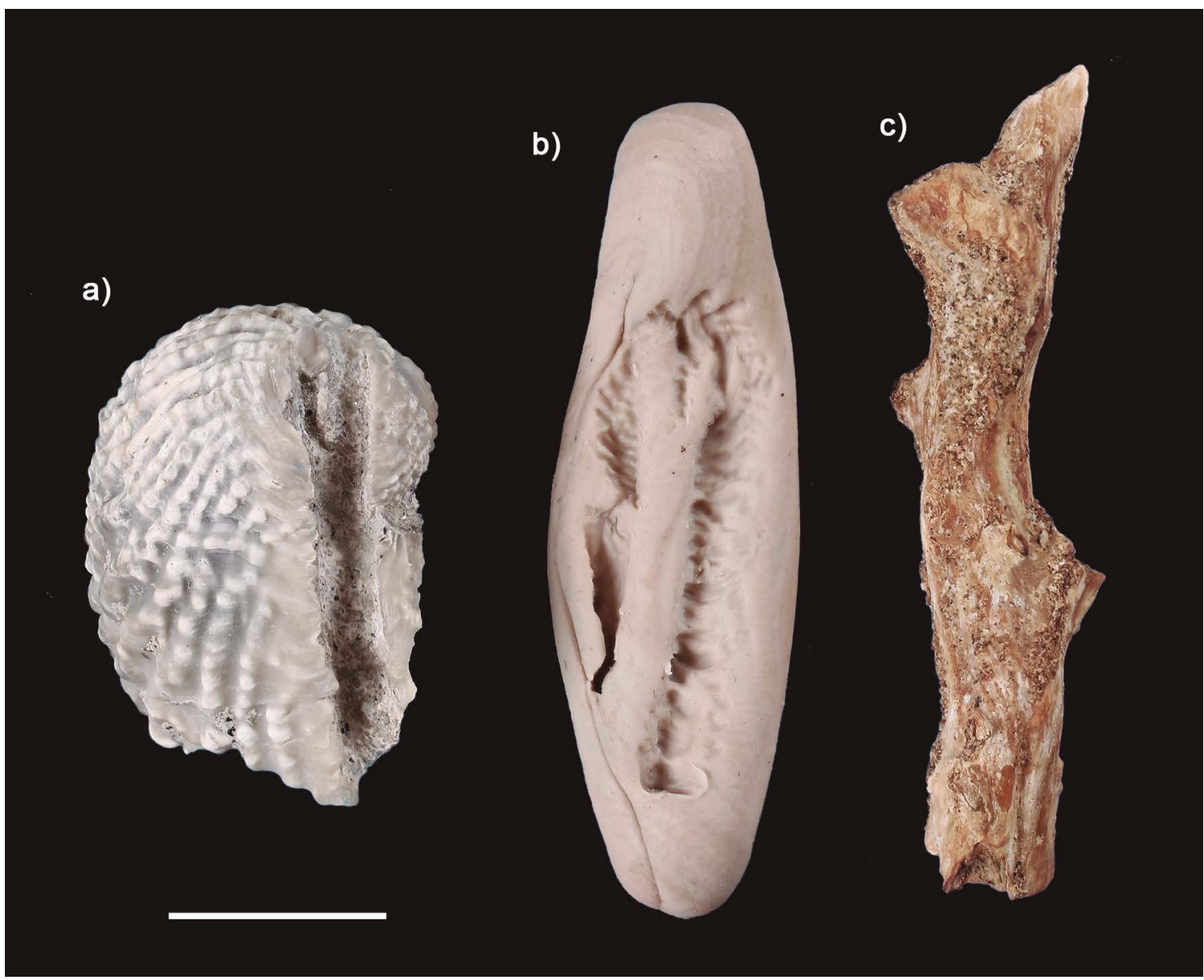

Figure 10. Exogyra attachment to a gorgonian. a) Attachment scar exhibiting a moldic impression of a bifurcating gorgonian axis (MMNS IP-9442.07). b) Clay impression of bioimmuration in a). c) Fragmentary section of a calcified gorgonian axis (MMNS IP-3262.10). Scale $=1 \mathrm{~cm}$. 
the Prairie Bluff seafloor as recorded in the current samples, Lerman (1965) did not report Exogyra attachment to non-skeletal materials like rocks, pebbles, and other nondescript objects. The Prairie Bluff phosphate pebbles are formed by the same biological processes that produced the steinkerns (e.g., Schulz and Schulz, 2005), and at least a third of the pebbles were suspected to be fragmentary mollusk steinkerns or their eroded remnants.

Substrates were comprised mostly of epifaunal remains at all localities (Figure 7). Given their availability on the surface, and that most epifauna utilized at the three localities were either calcitic and/ or thick-shelled, the frequency of this group in attachment scars is not surprising. The shells of infaunal organisms were next in importance in the two Prairie Bluff samples, but semi-infaunal shells were of at least equal importance at Owl Creek (OCR). If bottom energy is low (i.e., well below wave base), and seafloor has minimal disturbance, infauna should stay buried when they die, unless exhumed by bioturbators or predators. Even if infauna are exhumed, many common, relatively deep-dwelling forms have relatively thin, fragile shells (e.g., Panopea, Liopistha, and Pholadomya) that would succumb more readily to degradative processes on the seafloor. Infaunal taxa represented in Figure 7 are mostly the thick-shelled clam Cucullaea or the semiinfaunal mollusks Pinna and Turritella. Worth noting is the absence of Nucula among Exogyra bioimmurations at Owl Creek, where it is a common, thick-shelled infaunal bivalve, occasionally exhibiting predation holes from the infaunal naticid gastropod Gyrodes (Phillips, personal observation). Cucullaea may have been more common, and it was considerably larger $(3-6 \mathrm{~cm})$ and broader than the narrow Nucula (3-3.5 cm); this may partially explain its representation as an Exogyra substrate. Another possibility is that Cucullaea was being exhumed by a large epifaunal predator, but no evidence of this is readily apparent.

\section{"Absence of evidence..."}

The organisms not found in Exogyra bioimmurations are just as interesting, although some of the taxa may be represented among the unidentified, amorphous attachment scars. (We also recognize that our non-exhaustive sample sizes may contribute to limitations in taxa representation.) The following macrofossils are well-represented in the late Maastrichtian locality faunas of Sohl and Koch (1983) and several museum collections but were notably absent from our bioimmuration samples: plants, echinoid tests and plates, infaunal benthos (including burrowing echinoids and bivalves), crustaceans, and numerous aragonitic mollusk species.

Fragile, thin-shelled, less refractory objects, such as smaller gastropods and infaunal bivalves, are either poorly or unrepresented in the bioimmurations. Attachment scars reveal that substrates occasionally broke, sometimes multiple times, suggesting gradual decomposition of the object during overgrowth. Many of the unidentifiable impressions among the attachment scars are likely substrates that decomposed during overgrowth. Greater solubility and residence time on the surface of the middle shelf seafloor, where the carbonate-rich sediments of the Prairie Bluff Formation were deposited, were not favorable to the preservation of thin-shelled aragonitic mollusks.

Infaunal organisms would be ostensibly less available as substrate than epifaunal and semi-infaunal benthos. Deep infaunal bivalves like Panopea and Pholadomya, reported previously from area faunal lists compiled by Sohl and Koch (1983), are not represented among the attachment scars. Their absence could be due to their depth preference. Deeply burrowing taxa dying at depth would be understandably unavailable as potential substrate, unless bioturbation or storms sufficiently disturbed the seafloor, exposing the shells of deep infauna. Neither Panopea nor Pholadomya seem to be particularly common as body fossils and would have been equally scarce as potential substrate.
Although Liopistha is a relatively commonly encountered infaunal bivalve in the Prairie Bluff and Owl Creek Formations (Sohl and Koch, 1983), it was not detected in an Exogyra bioimmuration within our samples. Infaunal bivalves like Panopea, Pholadomya, and the almost ubiquitous Liopistha are all aragonitic and thin-shelled (compared to species of similar size), thus skeletal material of these fragile bivalves may have been vulnerable to dissolution and decomposition. Although they served as possible initial hosts of Exogyra, their shells may have persisted only long enough to support the oyster to a point at which any impression of these host bivalves was lost in any subsequent regrowth at the site of attachment.

The absence of scaphitid shells from Exogyra scars at OCR is at first perplexing given that Discoscaphites is commonly encountered nearly throughout the exposed section at the type locality (Sohl, 1964; Kennedy and Cobban, 2000; Larina et al., 2016). However, the interval, or surface, from where our sample is derived contains no conspicuous ammonites and may lack them entirely.

Echinoid body fossils were present but rare in all sampled intervals. The dome of the echinoid test would seem to make an excellent substrate for an epibiont, especially large, thick-shelled, semi-infaunal lamp urchins like Hardouinia. However, no specimens of Hardouinia hosting Exogyra were found in this study, nor in MMNS and DSM collections. Most echinoids occurring in the Owl Creek and Prairie Bluff formations are small, burrowing spatangoids (e.g., Hemiaster and Schizaster). Barring disturbance by bioturbation or storms, these infaunal macrobenthos would be unavailable to sclerobionts. The absence of echinoids as bioimmured taxa, except for evidence of attachment to echinoid spines, may also result from rapid disarticulation of the tests or low relative abundance among seafloor shell accumulations.

Impressions of crustacean remains, namely those of decapods, were undetected in our samples. Decapod remains as substrates must be a rare event given the poor preservation potential of chitin in alkaline sediments, particularly those of condensed beds that result from slow to hiatal deposition (e.g. Bishop, 1986). Bishop (1981) described an external mold of a lobster carapace in the attachment scar of an Exogyra costata from the Coon Creek Member of the Ripley Formation near Blue Springs, Mississippi. He speculated on the length of time it would take for decapod cuticle (from a dead lobster or its molt) to decompose on the seafloor. However, many of the decapod remains recovered by Bishop (1981) were body fossils preserved in (or as) phosphate nodules, with the exoskeletons frequently exposed on the surfaces of the nodules. These phosphatized decapods are concentrated in a conglomeratic condensed zone (Bishop, 1983) and occasionally possess calcareous sclerobionts other than Exogyra. Because of the stability provided by a hard, lithified substrate, and early, preburial phosphatization of decapod cuticle (e.g., Aguirre-Urreta et al., 2012), Bishop's (1981) Exogyra was likely attached to a previously permineralized lobster rather than a recently deceased one (or equally fresh molt), as originally suggested.

Plants were neither detected nor suspected among our bioimmured samples. However, it is possible they may yet be documented among the unidentified impressions. Oysters, fossil or living, have not been observed to attach to macroalgae, but seagrass functions as a substrate for this bivalve group in shallow waters (Taylor and Todd, 2001; Diedrich, 2008). Although the fouling of plants by bryozoans, mussels, and other epibenthos is common in the intertidal and shallow subtidal realm (e.g., Taylor, 1990), Exogyra was an unlikely epibiont because it lived in relatively deep subtidal environments (e.g., Stenzel, 1971), beyond or at the outer limits of the photic zone. Wood in the form of lignite was present at all localities, with the largest pieces observed at OCR. Lignitized wood at the Prairie Bluff localities was largely degraded. Although no lignitic residue was observed in any of the unidentified attachment scars, it is possible that waterlogged wood 
on the seafloor provided a substrate suitable to maturing spat. While surveying localities for the current study, a smaller subtidal gryphaeid (Gryphaeostrea) was observed attached to wood in the overlying early Paleocene Clayton Formation (Phillips, personal observation).

\section{Sample site comparisons}

Between-site comparisons are noteworthy, especially as regards the most abundant taxa identified in each sample of Exogyra bioimmurations. Mollusks were the dominant substrate across all sites, Bivalvia the most commonly utilized class (Figure 6) and Exogyra the most common substrate at the lowest taxonomic level (Table 1). Given the durability and preservability of the densely laminate, thick-shelled, calcitic valves of Exogyra, its broad availability is not surprising.

However, the condition of Exogyra substrate shells differs among sites. Auto-attachment at PBS occurred often on shell fragments rather than entire valves as at PBH and OCR. This is accordant with the greater exposure (residence time) and degradation in the transgressive beds of the basal Prairie Bluff in which the PBS sample was collected.

Gervilliopsis was the second most common substrate at OCR and $\mathrm{PBH}$ and body fossils of this clam were regularly encountered at both sites (shells at OCR; steinkerns at PBH). However, this bivalve was not detected among the Exogyra bioimmurations at PBS, nor as a macrofossil there. Gervilliopsis was a sedentary, epifaunal suspension feeder (PBDB, 2020) whose valves are frequently found in concentrations (Wingard, 2016). Whether such accumulations are due to gregarious behavior, abundance, or post-mortem concentration is unknown. However, oyster attachment to Gervilliopsis is not unknown. Regular attachment to Gervilliopsis by Exogyra was previously documented in the Campanian of New Jersey (Bernstein, 1986) and regular scarring observed in Campanian Exogyra populations in Mississippi and Arkansas (Phillips, personal observation). The related and ecomorphologically similar Gervillia from the Upper Jurassic of Poland was a common substrate for two palaeolophid oyster genera (Machalski, 1998). As also noted by Bernstein (1986), the broad surface area (Figure 3c, 3d), locally common accumulations, and epifaunal habit of Gervilliopsis made for an easy target with ample surface area for the developing oyster. We can offer no easy explanation for the absence of Gervilliopsis at PBS; Sohl and Koch (1983) did not detect it in any of their body-fossil samples from the Starkville (PBS) vicinity.

The sedentary, semi-infaunal suspension feeder Pinna is observed in vivo at OCR with some regularity. Pinna is a tall bivalve that embeds deeply in sandy mud, exposing only its posterior margin for filter-feeding and respiration (Rosewater, 1961). It further secures its purchase in the sediment by a byssus that attaches to buried shell fragments at the embedded acuminate umbonal end (Stanley, 1970). Deep rooting and byssal attachment help prevent uprooting by predators and strong currents (Rosewater, 1961; Stanley, 1970). Often reported as commonly occurring in modern seagrass meadows, fossil Pinnidae may have less value as a paleoenvironmental indicator than previously thought (Reich et al., 2015). Two of the identified bioimmurations in the OCR belong to this taxon, but its molds and body fossils were undetected in the Exogyra samples from the Prairie Bluff Formation (Table 1). Apparently, body fossils of Pinna are not common in this formation, at least not in the chalk-like facies of the Prairie Bluff (Sohl and Koch, 1983). Its absence at PBS is understandable. The sampled PBS interval lies at the base of the Prairie Bluff Formation, which represents a transgressive systems tract exhibiting characteristics of a rockground (Bryan, 1992). Firm surfaces are helpful to a byssally anchored bivalve like Pinna, but they are unhospitable to a relatively large, shallow burrower. The sampled intervals at OCR and PBH represent sediments associated with a maximum flooding surface, which are loose and seemingly more hospitable sediments. The scarcity of
Pinna at PBH may be related to the greater distance from shore than the sampled OCR interval-calcareous versus siliciclastic sediments, respectively. The abundance of phosphate, siderite, and glauconite in the vicinity of the $\mathrm{PBH}$ oyster bed suggests the proximity of a surface of maximum starvation associated with the maximum flooding surface, which often produce hardgrounds and rockgrounds in other settings (e.g., Bryan, 1992), but indicating at least a partially cemented seafloor or firmground. The scarcity of bioimmured shallow infaunal taxa and lack of deep infaunal taxa associated with the Exogyra bed at PBH is consistent with this interpretation.

Cucullaea capax Conrad is a locally common infaunal suspension feeding bivalve in upper Maastrichtian sediments of the Gulf Coastal Plain (e.g., Bottjer, 1981). The third most identified substrate at OCR and PBS, it was less commonly utilized in the PBH (Table 1). Its presence in the loose, sandy clay of the Owl Creek Formation comes as no surprise, but the PBS is a rockground with presumably very shallow loose sediment. Also, the PBS Exogyra did not attach to steinkerns of Cucullaea (Idonearca), although most of the basal Prairie Bluff mollusk fauna is known primarily through this type of preservation. Phosphatic steinkerns can be temporally problematic as they are easily reworked, resulting in some cases from deflation of an old, subjacent, pre-transgressive facies, e.g., lowstand systems tract of the upper Ripley Formation (Mancini et al., 1996) —or possibly even older.

\section{CONCLUDING THOUGHTS}

Our research provides an overview of the available substrates used by Exogyra on the Late Cretaceous seafloor on the eastern side of the Mississippi Embayment. Exogyra attached to cultch composed dominantly of macroinvertebrate skeletal debris - the only surfaces available to sclerobionts at the sampled localities, or throughout the Gulf Coastal Plain, based on the sedimentary and body fossil record. Survivorship of settling Exogyra larvae seems to have been more pronounced on some taxonomic groups than others, but whether this success was due to the greater relative abundance of certain skeletal taxa over others or greater suitability of some substrates over others (based textures, microbial films, or other settling cues), or some combination of the two, is indeterminable.

When bivalves were used as substrates, Exogyra attachment scars reveal that epibenthic taxa were utilized more than infaunal forms, presumably due to the lack of availability of the latter if they remain buried at depth postmortem. However, among the epibenthic species recorded in Exogyra bioimmurations, there is a dearth of thin-shelled and aragonitic forms. For example, Sohl $(1960,1964)$ and Sohl and Koch (1983) document a great diversity of gastropods in the late Maastrichtian of central Gulf Coastal Plain, including the localities sampled here, but diversity within this group was low. That said, Turritella is easily counted as the commonest large $(>1.5 \mathrm{~cm})$ gastropod by even the casual observer at Owl Creek (OCR), so it is not surprising that it constituted the greater proportion of gastropod bioimmurations at that location (Table 1). Large size and abundance may explain the availability of valves of the infaunal Cucullaea.

Based on material from three localities, our analysis of Exogyra attachment scars also suggests that the taxonomic diversity of substrates increased with distance from the latest Cretaceous shore, which is essentially equivalent to increasing depth from north to south along the eastern side of the Mississippi Embayment axis. This seems counterintuitive given the much greater molluscan diversity reported in general for the Owl Creek Formation (Table S2 of the Supplementary Material). However, the ostensibly greater biological diversity for that unit is totaled from multiple intervals, whereas the OCR Exogyra 
sample interval was confined to a discrete layer within the Owl Creek Formation-the Exogyra bed, which is interpreted here as representing a maximum flooding surface (see Mancini et al., 1996). The macrofossil content of the Owl Creek Exogyra bed observed and collected by the writers does not seem to have the diversity observed for higher beds (Larina et al., 2016) or what might be totaled for the entire unit.

\section{ACKNOWLEDGMENTS}

We are grateful to Suzanne Coffey, Kathy Bardwell Curto, Charlie Gardner, and Waste Management, Inc., for permissions in accessing sample sites. Brent Funderburk aided in locating several important localities. Gary Williams of the California Academy of Sciences assisted with the initial identification of Mississippi pennatulaceans (2008). Lastly, many thanks to Andrew Rindsberg and Miguel Torres-Martínez for their helpful, attentive reviews. Andrew Rindsberg was particularly encouraging and provided many insightful suggestions to improve the quality of the manuscript.

\section{SUPPLEMENTARY MATERIAL}

Supporting supplementary Tables S1 and S2 can be found at the journal web site $<$ http://rmcg.unam.mx/ $>$, in the html version of this paper.

\section{REFERENCES}

Aguirre-Urreta, B., Lazo, D.G., Rawson, P.F., 2012, Decapod Crustacea from the Agrio Formation (Lower Cretaceous) of the Neuquén Basin, Argentina: Palaeontology, 55(5), 1091-1103.

Agostini, V.O., Ritter, M.D.N., Macedo, A.J., Muxagata, E., Erthal, F., 2017, What determines sclerobiont colonization on marine mollusk shells? PLoS One, 12(9):e0184745.

Bayne, B., 2017, Biology of oysters: Cambridge, Massachusetts, Academic Press, $860 \mathrm{pp}$.

Bernstein, M.R., 1986, Taxonomic and stratigraphic interpretation of exogyrine oysters (Exogyra, Amphidonte) in the Upper Cretaceous Woodbury Formation in southern New Jersey: Northeastern Geology, 8(1/2), 4-12.

Bertling, M., Braddy, S.J., Bromley, R.G., Demathieu, G.R., Genise, J., Miluláš, R., Nielsen, J.K., Nielsen, K.S.S., Rindsberg, A.K., Schlirf, M., Uchman, A., 2006, Names for trace fossils: A uniform approach: Lethaia, 39, 265-286.

Bicker, A.R., 1969, Geologic map of Mississippi, 1:500,000: Mississippi Office of Geology, Jackson, Mississippi, 1 map.

Bishop, G.A., 1981: The lobster Linuparus preserved as an attachment scar on the oyster Exogyra costata, Ripley Formation (Late Cretaceous), Union County, Mississippi: Mississippi Geology, 2(1), 2-5.

Bishop, G.A., 1983, Fossil decapod Crusteacea from the Late Cretaceous Coon Creek Formation, Union County, Mississippi: Journal of Crustacean Biology, 3, 417-430.

Bishop, G.A., 1986, Occurrence, preservation, and biogeography of the Cretaceous crabs of North America, in Gore, R.H., Heck, K.L. (eds.), Crustacean issues Vol. 4, Crustacean biogeography: Rotterdam, Balkema Press, 111-142.

Bonar, D.B., Coon, S.L., Walch, M., Weiner, R.M., Fitt, W., 1990, Control of oyster settlement and metamorphosis by endogenous and exogenous chemical cues: Bulletin of Marine Science, 46(2), 484-498.

Bottjer, D.J., 1981, Structure of Upper Cretaceous chalk benthic communities, southwestern Arkansas: Palaeogeography, Palaeoclimatology, Palaeoecology, 34, 225-256.

Bryan, J.R., 1992, Origin and paleoecology of Maastrichtian rockground and chalk facies in southcentral Alabama: Palaios, 7, 67-76.

Catuneanu, O., Galloway, W.E., St. C. Kendall, C.G., Miall, A.D., Posamantier, H.W., Strasser, A., Tucker, M.E., 2011, Sequence stratigraphy: Methodology and nomenclature: Newsletters on Stratigraphy, 44(3), 173-245.

Chave, K.E., 1954, Aspects of biogeochemistry of magnesium; 1. Calcareous marine organisms: The Journal of Geology, 62(3), 266-283.

Chave, K.E., 1962, Factors influencing the mineralogy of carbonate sediments: Limnology and Oceanography, 7, 218-233.

Cooper, M.R., 1992, Pycnodontine oysters from the Upper Cretaceous of Zululand: Durban Museum Novitates, 17, 23-57.

Diedrich, C.G., 2008, The food of the miosiren Anomotherium langenwieschei (Siegfried)-Indirect proof of seaweed or seagrass by xenomorphic oyster fixation structures in the upper Oligocene (Neogene) of the Doberg, Bünde (NW Germany) and comparisons to modern Dugong dugon (Müller) feeding strategies: Senckenbergiana Maritima, 38(1), 59-73.

Galtsoff, P.S., 1964, The American oyster Crassostrea virginica Gmelin: Washington, D.C., U.S. Fish and Wildlife Service, 456 pp.

Griffin, J.E., Jr., Gibson, M.A., 1999, Bioimmuration of Exogyra from the Late Cretaceous Coon Creek Formation of west Tennessee: Journal of the Tennessee Academy of Science, 74(1-2), 27.

Harper, E.M., 1992, Post-larval cementation in the Ostreidae and its implications for other cementing Bivalvia: Journal of Molluscan Studies, 58, 37-47.

Harper, E.M., 2012, Part N, Revised, Volume 1, Chapter 21: Cementing Bivalvia: Treatise Online, 45, 1-12.

Hickson, S.J., 1938, An alcyonarian from the Eocene of Mississippi: Journal of the Washington Academy of Sciences, 28, 49-51.

Horton, J.D., 2017, The State Geologic Map Compilation (SGMC) geodatabase of the conterminous United States (ver. 1.1, August 2017): U.S. Geological Survey data release, doi.org/10.5066/F7WH2N65.

Jablonski, D., Bottjer, D.J., 1983, Soft-bottom epifaunal suspension-feeding assemblages in the Late Cretaceous: Implications for the evolution of benthic paleocommunities, in Tevesz, M.J.S., McCall, P.L. (eds.), Biotic interactions in Recent and fossil benthic communities: Plenum Press, New York, 747-812.

Kennedy, W.J., Cobban, W.A., 2000, Maastrichtian (Late Cretaceous) ammonites from the Owl Creek Formation in northeastern Mississippi, U.S.A.: Acta Geologica Polonica, 50(1), 175-190.

Kocurko, M.J., Kocurko, D.J., 1992, Fossil Octocorallia of the Red Bluff Formation, lower Oligocene, Mississippi: Journal of Paleontology, 66(4), 594-602.

Koppka, J., 2015, Revision of the Bivalvia from the Upper Jurassic Reuchenette Formation, northwest Switzerland-Ostreoida: Zootaxa, 3927(1), 1-117.

LaBarbera, M., 1981, The ecology of Mesozoic Gryphaea, Exogyra, and Ilymatogyra (Bivalvia: Mollusca) in a modern ocean: Paleobiology, 7(4), 510-526.

Larina, E., Garb, M., Landman, N., Dastas, N., Thibault, N., Edwards, L., Phillips, G., Rovelli, R., Myers, C., Naujokaityte, J., 2016, Upper Maastrichtian ammonite biostratigraphy of the Gulf Coastal Plain (Mississippi Embayment, southern USA): Cretaceous Research, 60, 128-151.

Lerman, A., 1965, Evolution of Exogyra in the Late Cretaceous of the southeastern United States: Journal of Paleontology, 39(3), 414-435.

Machalski, M., 1998, Oyster life positions and shell beds from the Upper Jurassic of Poland: Acta Palaeontologica Polonica, 43(4), 609-634.

Malchus, N., 1996, Palaeobiogeography of Cretaceous oysters (Bivalvia) in the western Tethys: Mitteilungen aus dem Geologisch-paläontologischen Institut der Universität Hamburg, 77, 165-181.

Malchus, N., Aberhan, M., 1998, Transitional gryphaeate/exogyrate oysters (Bivalvia: Gryphaeidae) from the Lower Jurassic of northern Chile: Journal of Paleontology, 72(4), 619-631.

Mancini, E.A., Puckett, T.M., Tew, B.H., 1996, Integrated biostratigraphic and sequence stratigraphic framework for Upper Cretaceous strata of the eastern Gulf Coastal Plain, USA: Cretaceous Research, 17, 645-669.

McClure, M., Bohonak, A.J., 1995, Non-selectivity in extinction of bivalves in the Late Cretaceous of the Atlantic and Gulf Coastal Plain of North America: Journal of Evolutionary Biology, 8, 779-794.

Nielsen, K.B., 1914, Moltkia isis Steenstrup og andre Octocorallia fra Danmarks Kridttidsaflejringer: Mindeskrift i aniedning afhundredaaret for Japetus Stecnstrups fodsel, Kobenhavn, 18, 1-20.

Nielsen, K.B., 1917, Heliopora incrustans n. sp., with a survey of the Octocorallia in the deposits of the Danian of Denmark: Meddelelser fra Dansk geologisk Forening, 5(8), 3-13.

Paleobiology Database (PBDB), 2020, Exogyra, genus in Bivalvia: Paleobiology 
Database, paleobiodb.org/classic/basicTaxonInfo?taxon_no=16655, data download 29 July 2020.

Parras, A., Casadío, S., 2005, Taphonomy and sequence stratigraphic significance of oyster-dominated concentrations from the San Julián Formation, Oligocene of Patagonia, Argentina: Palaeogeography, Palaeoclimatology, Palaeoecology, 217(1-2), 47-66.

Peterson, P., Smith, L., Gailloreto, N., Hanger, R.A., 2009, Paleoecology of the middle Cretaceous Walnut Formation, Bell County, Texas: Geological Society of America Abstracts, 41(4), 16.

Phillips, G.E., 2010, A distinctive lithofacies between the Prairie Bluff and Owl Creek formations (Upper Cretaceous) of north Mississippi and its characteristic faunal content: Journal of the Mississippi Academy of Sciences, 55(1), 78.

Reich, M., Kutscher, M., 2011, Sea pens (Octocorallia: Pennatulacea) from the Late Cretaceous of northern Germany: Journal of Paleontology, 85(6), 1042-1051.

Reich, S., Di Martino, E., Todd, J.A., Wesselingh, F.P., Renema, W., 2015, Indirect paleo-seagrass indicators (IPSIs): A Review: Earth-Science Reviews, 143, 161-186.

Richards, H.G., 1958, The Cretaceous Fossils of New Jersey, Part 1 - Porifera, Coelenterata, Annelida, Echinoidea, Brachiopoda and Pelecypoda: Trenton, New Jersey, New Jersey Department of Conservation and Economic Development, 266 pp.

Richards, H.G., 1962, The Cretaceous Fossils of New Jersey, Part 2 - Gastropoda, Scaphopoda, Nautiloidea, Ammonoidea, Belemnitidae, Crustacea, Vertebrata and miscellaneous fossils: Trenton, New Jersey, New Jersey Department of Conservation and Economic Development, 237 pp.

Roemer, F.A., 1849, Texas, mit besonderer Riicksicht auf deutsche Auswanderung und die physischen Verhaltnisse des Landes nach eigener Beobachtung geschildert von Dr. Ferdinand Roemer: Bonn, Germany, A. Marcus, 464 pp.

Rohr, D.M., Boucot, A.J., 1989, Xenomorphism, bioimmuration, and biologic substrates: An example from the Cretaceous of Brazil: Lethaia, 22, 213-215.

Rosewater, J., 1961, The family Pinnidae in the Indo-Pacific, in Abbott, T.R. (ed.), Indo-Pacific Mollusca, Volume 1: Philadelphia, Academy of Natural Sciences, $175-226$.

Rubilar, A.E., Lazo, D.G., 2009, Description of Aetostreon pilmatuegrossum sp. nov. from the Lower Cretaceous of Argentina (Neuquén Basin), and significance of the conservative left valve morphology in oysters of the genus Aetostreon Bayle: Cretaceous Research, 30, 727-748.

Say, T., 1820, Observations on some species of zoophytes, shells, etc., principally fossil (part 2): American Journal of Science and Arts, 2(1), 34-45.

Seilacher, A., Matyja, B.A., Wierzbowski, A., 1985, Oyster beds: Morphologic response to changing substrate conditions, in Bayer, U., Seilacher, A. (eds.), Sedimentary and evolutionary cycles: Berlin and Hiedelberg, SpringerVerlag, 421-435.

Schulz, H.N., Schulz, H.D., 2005, Large sulfur bacteria and the formation of phosphorite: Science, 307, 416-418.

Scott, R.W., Claggett, B.W., 2018. Albian infaunal Pholadomyida (Cretaceous Bivalvia), Comanchean carbonate shelf, Texas: Journal of Paleontology, 92(4), 611-633.

Sha, J., Smith, P.L., Fürsich, F.T., 2002, Jurassic Ostreoida (Bivalvia) from China (Tanggula Mountains, Qinghai-Xizang Plateau) and their paleobiogeographic context: Journal of Paleontology, 73(3), 431-446.

Skinner, H.C., Jahren, A.H., 2003, Biomineralization: Treatise on Geochemistry, $8,117-184$.

Sohl, N.F., 1960, Archeogastropoda, Mesogastropoda, and stratigraphy of the Ripley, Owl Creek, and Prairie Bluff Formations: U.S. Geological Survey Professional Paper, 331(A), 1-151.
Sohl, N.F., 1964, Neogastropoda, Opisthobranchia and Basommatomorpha from the Ripley, Owl Creek, and Prairie Bluff Formations: U.S. Geological Survey Professional Paper, 331(B), 152-344.

Sohl, N.F., Koch, C.F., 1983, Upper Cretaceous (Maestrichtian) Mollusca from the Haustator bilira Assemblage Zone in the East Gulf Coastal Plain: U.S. Geological Survey Open File Report, 83(451), 1-239.

Stanley, S.M., 1970, Relation of shell form to life habits of the Bivalvia (Mollusca): Boulder, Colorado, Geological Society of America, 296 pp.

Stanley, S.M., 2015, Part N, Revised, Volume 1, Chapter 19: Evolutionary ecology of the Bivalvia: Treatise Online, 72, 1-48.

Stenzel, H., 1971, Oysters, in Moore, R.C. (ed.), Part N, Mollusca 6, Bivalvia 3: Boulder, Colorado, and Lawrence, Kansas, Geological Society of America and University of Kansas, 953-1224.

Stephenson, L.W., 1914, Cretaceous deposits of the Eastern Gulf Region and species of Exogyra from the Eastern Gulf Region and the Carolinas: U.S Geological Survey Professional Paper, 81, 1-77.

Stephenson, L.W., 1923, Invertebrate fossils of the Upper Cretaceous Formations, in Stephenson, L.W. (ed.), The Cretaceous Formations of North Carolina, Vol. 5, Part 1: Raleigh, North Carolina, North Carolina Geological Survey, 1-402.

Stephenson, L.W., 1941, The larger invertebrate fossils of the Navarro Group of Texas (exclusive of corals and crustaceans and exclusive of the fauna of the Escondido Formation): Austin, Texas, University of Texas, $641 \mathrm{pp}$.

Stephenson, L.W., 1955, Owl Creek (Upper Cretaceous) fossils from Crowleys Ridge southeastern Missouri: U.S. Geological Survey Professional Paper, 274(E), 97-140.

Taylor, P.D., 1990, Preservation of soft-bodied and other organisms by bioimmuration - A review: Palaeontology, 33(1), 1-17.

Taylor, P.D., Todd, J.A., 1990, Sandwiched fossils: Geology Today, 6, 151-154.

Taylor, P.D., Todd, J.A., 2001, Bioimmuration, in Briggs, D.E.G., Crowther, P.R. (eds.), Palaeobiology II: Malden, Massachusetts, Blackwell Publishing, 285-289.

Todd, J.A., 1993, The bivalve shell as a preservation trap, as illustrated by the Late Jurassic gryphaeid, Deltoideum delta Smith: Scripta Geologica, Special Issue 2, 417-433.

Wade, B., 1926, The fauna of the Ripley Formation on Coon Creek, Tennessee: U.S. Geological Survey Professional Paper, 137, 1-272.

Weller, S., 1907, A report on the Cretaceous paleontology of New Jersey: Trenton, New Jersey, New Jersey Geological Survey, 1107 pp.

White, C.A., 1884, A review of the fossil Ostreidae of North America and a comparison of the fossil with living forms: Annual Report of the U.S. Geological Survey, 4(1882-1883), 273-431.

Whitfield, R.P., 1885, Brachiopoda and Lamellibranchiata of the Raritan clays and greensand marls of New Jersey: Washington, D.C., U.S. Geological Survey, $338 \mathrm{pp}$.

Williams, G.C., 1999, Index Pennatulacea: Annotated bibliography and indexes of the sea pens (Coelenterata: Octocorallia) of the world, 1469-1999: Proceedings of the California Academy of Sciences, 51(2), 19-103.

Wingard, G.L., 2016, Review of Norman F. Sohl's contributions to research at Coon Creek, Tennessee: Alabama Museum of Natural History Bulletin, 33(1), 20-33

Yonge, C.M., 1960, Oysters: London, NMN Collins, 209 pp

Manuscript received: june 10, 2020

Corrected manuscript received: september 5, 2020

Manuscript accepted: september 5, 2020 